\title{
ABANDONING COPYRIGHT
}

\section{Dave Fagundes* \& Aaron Perzanowski**}

For nearly two hundred years, U.S. copyright law has assumed that owners may voluntarily abandon their rights in a work. But scholars have largely ignored copyright abandonment, and the case law is fragmented and inconsistent. As a result, abandonment remains poorly theorized, owners can avail themselves of no reliable mechanism to abandon their works, and the practice remains rare. This Article seeks to bring copyright abandonment out of the shadows, showing that it is a doctrine rich in conceptual, normative, and practical significance. Unlike abandonment of real and chattel property, which imposes significant public costs in exchange for discrete private benefits, copyright abandonment is potentially costly for rights holders but broadly beneficial for society. Nonetheless, rights holders-ranging from lauded filmmakers and photographers to leading museums and everyday creators - make the counterintuitive choice to abandon valuable works. This Article analyzes two previously untapped resources to better understand copyright abandonment. First, we survey four decades U.S. Copyright Office records, demonstrating both the motivations for abandonment and the infrequency of the practice. Second, we examine every state and federal copyright abandonment case, a corpus of nearly 300 decisions. By distilling this body of law, this Article distinguishes abandonment from a set of related doctrines and reveals the major fault lines in judicial application of the abandonment standard. Finally, we highlight the potential of abandonment to further copyright's constitutional aims by suggesting a series of reforms designed to better align copyright holder incentives with the public good.

\footnotetext{
* Baker Botts LLP Professor of Law, Assistant Dean for Faculty Development, University of Houston Law Center.

${ }^{* *}$ Professor of Law, Oliver C. Schroeder Jr. Distinguished Research Scholar, Case Western Reserve University.

Our thanks to Ellen Boyd, Kathleen Burke, and David Cruz for outstanding research assistance, to Zvi Rosen for his help navigating Copyright Office records, and to Clark Asay, Mark Bartholomew, Sarah Burstein, Michael Carroll, Bryan Choi, Margaret Chon, Jorge Contreras, Rebecca Curtin, Brian Frye, Dmitry Karshtedt, Jake Linford, Yvette Liebesman, Lydia Loren, Mike Madison, Michael Mattioli, Jan Osei-Tutu, Blake Reid, Guy Rub, Andres Sawicki, Martin Skladany, Amelia Rinehart, Jessica L. Roberts, Jennifer Rothman, Zahr Said, Lior Strahilevitz, Shine $\mathrm{Tu}$, and Rebecca Tushnet, as well as participants in the Association of Law Property \& Society (ALPS) Annual Meeting, Intellectual Property Scholars Conference (IPSC), M3 IP Workshop, Three Rivers IP and Tech Law Colloquium, University of Houston Law Center Internal Faculty Workshop Series, and Works In Progress IP (WIPIP) meetings, for their comments on prior drafts.
} 


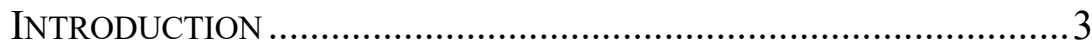

I. CONCEPTUALIZING ABANDONMENT ……………………..........

A. Abandoning Property ..................................................

B. Abandoning Copyrights .............................................. 10

II. THE SOCIAL COSTS OF ABANDONMENT ..................................... 14

A. The Social Costs of Abandoning Physical Property... 14

B. The Social Benefits of Abandoning Copyrights ..........16

1. Private Welfare Effects .......................................... 16

2. Public Welfare Effects ........................................... 19

C. Revealed Preferences \& Attempted Abandonment ....31

III. THE LAW OF COPYRIGHT ABANDONMENT ................................36

A. Statutory Silence ………………………………….......

B. Administrative Agnosticism ..........................................38

C. Judicial Uncertainty .....................................................4 43

1. Distinguishing Adjacent Doctrines .........................44

2. The Unsettled Black Letter of Abandonment ........47

IV. OPTIMIZING ABANDONMENT ..............................................59

A. Illuminating a Pathway to Abandonment .....................60

B. Recalibrating Incentives...............................................64

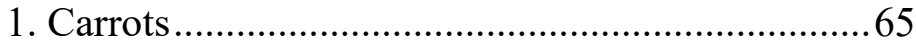

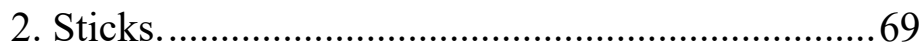

C. Availability and Abandonment as a Social Practice...70

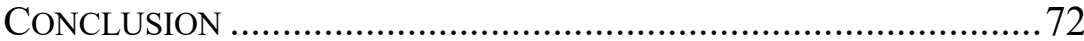




\section{INTRODUCTION}

Copyright vests automatically, whether authors want it or not. The author of an original work is a copyright holder from the instant that work is fixed in some durable form. ${ }^{1}$ But what if you don't want to own a copyright in the photo you just took or the song you just wrote? ${ }^{2}$ Or what if, for reasons of personal gain or pure altruism, you want to abandon your existing copyright and place your work in the public domain?

In theory, copyright owners, like owners of chattel property, may abandon their works. ${ }^{3}$ In fact, copyright law borrowed its legal test for abandonment from common-law property doctrine. In practice though, it remains far from clear how an author can actually relinquish rights in a work. The Copyright Act makes no mention of abandonment, and there is no standard form to file with the Copyright Office. In light of this, courts have been understandably conflicted about what acts reflect an intent to abandon. And even if the law did offer a clear pathway for authors to abandon their copyrights, there is no single, definitive registry of abandoned works for would-be users to consult. 4

The uncertainty surrounding these elementary questions of copyright ownership is problematic, in part, because it frustrates abandonment's potential to enrich the increasingly starved public domain. Copyright's constitutional lodestar-promoting the progress

\footnotetext{
${ }^{1}$ See 17 U.S.C. $§ 102(a)$ (2018).

${ }^{2}$ Aside from works created by the federal government or those that fail copyright's minimal eligibility standards, there is no mechanism under current U.S. law to prevent copyright from vesting as an initial matter. See id. $§ 105$.

${ }^{3}$ We focus here on U.S. copyright law. But there is considerable variation among jurisdictions on the question of copyright abandonment. Under United Kingdom law, the availability of abandonment is far from clear, and statements purporting to abandon copyright may be interpreted as mere revocable licenses. See Phillip Johnson, 'Dedicating' Copyright to the Public Domain, 71 MoD. L. Rev. 587, 5968 (2008). And German courts have rejected the idea of abandonment. See GrAHAM GreEnleaf \& David Lindsay, Public Rights: Copyright's Public Domains 512 (2018) (citing Berlin Wall Pictures, Federal Court of Justice (Bundesgerichtshof BGH) Feb. 23, (1995) GRUR 673, (1997) 28 IIC 282). Other jurisdictions-Chile, Colombia, India, and Kenya among them - expressly recognize abandonment. See Andres Guadamuz, Comparative Analysis of National Approaches on Voluntary Copyright Relinquishment, WIPO COMMITTEE ON DEVELOPMENT AND INTELLECTUAL PROPERTY (2014).

${ }^{4}$ Cf. Robert Merges, To Waive and Waive Not: Property and Flexibility in the Digital Era, 34 COLUM. J.L. \& ARTS 113 (2011) (reflecting on the surprising difficulty of abandoning copyrights).
} 
of science-presumes a healthy balance between privately owned works and publicly available material. But after decades of unremittingly copyright-holder-friendly reforms, this balance has tipped significantly toward private rights at the expense of the public. Legislation extending the term of copyright and eliminating formal requirements for protection has slowed to a trickle the flow of works into the public domain. In light of these trends, an invigorated abandonment doctrine promises a voluntary means to replenish the desiccated public domain well before statutory expiration of copyright.

The desire among authors to part with their copyrights in order to enrich the public domain is not merely theoretical. Rights holders have attempted to abandon their rights in millions of photos, including hundreds of thousands from the Metropolitan Museum of Art alone. Acclaimed photographer Carol Highmsith sought to abandon her rights in tens of thousands of images donated to the Library of Congress. Likewise, award-winning filmmaker Nina Paley expressed her desire to place her film Sita Sings the Blues in the public domain. And more than 100,000 software projects hosted on GitHub indicate the developers' intention to abandon copyright. Other times, abandonment arises as a defense, as when InfoWars claimed it did not infringe Matt Furie's "Pepe the Frog" because Furie's public statements indicated that he had abandoned the character. ${ }^{5}$ Given the state of the law, however, whether these owners actually have abandoned their copyrights remains unclear.

The disarray pervading the law and practice of copyright abandonment has not inspired much scholarly examination. ${ }^{6}$ This is

\footnotetext{
${ }^{5}$ InfoWars eventually paid Furie $\$ 15 \mathrm{~m}$ to settle the suit as a jury trial loomed, suggesting that InfoWars' abandonment argument may not have been that compelling. Eriq Gardner, InfoWars Pays \$15m to Settle “Pepe the Frog” Lawsuit, The Hollywood Reporter, June 10, 2019, available at https://www.hollywoodreporter.com/thr-esq/infowars-pays-15k-settle-pepe-frogcopyright-lawsuit-1217193.

6 Timothy K. Armstrong, Shrinking the Commons: Termination of Copyright Licenses and Transfers for the Benefit of the Public, 47 HARV. J. LEGIS. 359 (2010); Tom W. Bell, Escape from Copyright: Market Success vs. Statutory Failure in the Protection of Expressive Works, 69 U. Cin. L. Rev. 741 (2001); Johnson, supra note 3; Lydia Pallas Loren, Building A Reliable Semicommons of Creative Works: Enforcement of Creative Commons Licenses and Limited Abandonment of Copyright, 14 Geo. Mason L. Rev. 271 (2007); Lydia Pallas Loren, Abandoning the Orphans: An Open Access Approach to Hostage Works, 27 BerKELEY TECH. L.J. 1431 (2012).
} 
unsurprising. Until the pioneering work of Eduardo Peñalver and Lior Strahilevitz, abandonment of physical property received little attention from scholars either. Yet Peñalver and Strahilevitz showed that, despite the dearth of attention paid to the topic, abandonment of physical property is a rich topic worthy of careful scrutiny. ${ }^{7}$

Similarly, this Article seeks to illuminate the largely ignored law and policy of copyright abandonment. We make the case that, just as with physical property, copyright abandonment is a question of practical and theoretical significance that deserves greater attention. The very notion of abandoning copyright is fraught with conceptual difficulty. The leading theory of abandonment - unilateral transferis an admittedly poor fit for copyright since abandonment results in a public good rather than a resource that can be claimed by a particular owner. ${ }^{8}$ Moreover, the thing protected by copyright - the work of authorship - is an abstraction, rather than a corporeal object. So while one can conceive of easy ways to abandon a chattel — putting your old TV on the curb with a sign reading "free", for example-expressing your intention to abandon rights in a work of authorship presents a much thornier challenge. Further, it is easy to imagine reasons that owners may want to abandon physical property: old furniture takes up space, a boat requires upkeep, and there is perhaps peace to be found in purging clutter. ${ }^{9}$ But copyrights take up no space and cost nothing to maintain, so it seems counterintuitive that authors would ever give up rights in a work. That said, the fact remains that owners do express the desire to give up rights in their works with no pecuniary reward in mind, however much this may frustrate the predictions of rationalchoice economics.

Copyright abandonment also presents a distinctive doctrinal tangle. Blackletter law outlines the same basic test for relinquishing rights in a work as it does for chattels: intent to abandon, plus some overt act evidencing that intent. And while there were legal mechanisms for abandoning a copyright under prior regimes, the 1976 Act jettisoned those formal requirements, leaving owners without any clear pathway to place their work in the public domain. ${ }^{10}$ Courts have,

\footnotetext{
${ }^{7}$ Eduardo M. Peñalver, The Illusory Right to Abandon, 109 Mich. L. REV. 191 (2010); Lior Jacob Strahilevitz, The Right to Abandon, 158 U. PA. L. REV. 355 (2010).

${ }^{8}$ See infra Part I.B.

${ }^{9}$ See generally Marie Kondo, The Life-Changing Magic OF Tidying Up (2014); Margareta Magnusson, The Gentle Art of Swedish Death Cleaning (2018).

${ }^{10}$ See infra Part III.A.
} 
however, continued to apply the common-law abandonment doctrine under the post-76 Act regime, albeit with conflicting results that fail to give authors clarity as to what acts are sufficient to inject their works into the public domain.

As a result, the law frustrates otherwise aligned individual and social preferences. Many copyright owners would like to abandon their works, including some high-value ones. Abandonment of such works would advance copyright's constitutional goals by enriching the public domain. Yet copyright law itself remains a stumbling block because of the muddled doctrinal and administrative structure of abandonment.

This Article seeks to resolve this tension between the revealed preferences of creators and the constitutional goals of copyright law, on the one hand, and the interpretation and application of the law, on the other. It explores the theoretical and doctrinal terrain of copyright abandonment in order to outline reforms that could help abandonment serve copyright law's constitutional aims. It does so in four parts.

Part I briefly outlines the conceptual foundations of abandonment in the contexts of both physical property and copyright. In Part II, we turn to the welfare effects of abandonment, contrasting the cost-benefit dynamic in physical property - characterized by high private benefit but high social costs - to that of copyright - marked by low private benefit and high social benefit. Despite this reversal in the cost-benefit calculus, we demonstrate that rights holders nonetheless seek to abandon their works for a variety of reasons. As Part III details, however, even for copyright holders who prefer to abandon their works, the legal framework for doing so remains unhelpfully opaque. This analysis is based on our exhaustive examination of two previously unappreciated datasets. First, we collected and reviewed notices of abandonment filed with the Copyright Office over the last forty years. Second, we evaluated nearly three hundred judicial decisions, dating back to the early nineteenth century, that analyzed copyright abandonment. Our analysis establishes a number of descriptive claims about copyright abandonment, primarily that neither statutory, administrative, nor judicial copyright law provide a particularly clear path for those seeking to abandon their works, or for those hoping to mine the public domain. Finally, we outline a number of potential reforms to facilitate and optimize abandonment in Part IV. 


\section{CONCEPTUALIZING ABANDONMENT}

Abandonment, as a legal concept, remains poorly understood. Although Strahilevitz and Peñalver made important inroads with respect to chattel abandonment, no similar work has investigated the fundamental nature of copyright abandonment. ${ }^{11} \mathrm{We}$ begin by first exploring how the doctrine works in the context of physical property. We then consider how the existing accounts of abandonment track onto copyright. In so doing, we offer a theory of abandonment that rejects the leading notion of abandonment as unilateral transfer in favor of one that instead models abandonment as the owner's relinquishment of a legal relationship with their property.

\section{A. Abandoning Property}

The familiar constituent rights of property owners-use, exclusion, and transfer - do not include the right to abandon. Yet there is an intuitive sense that if an owner does not want to continue owning something, it would be strange for law to prevent her from doing so. ${ }^{12}$ As J.E. Penner observed, "an unbreakable relation to a thing would condemn the owner to having to deal with it. It would indeed be a funny turn of events if ... property in essence gave the things a person owned a power over him." 13 Penner's observation is rooted in a conception of property committed to individual autonomy. ${ }^{14}$ If ownership is an institution that both embodies and protects individual liberty, then owners need the right to abandon, or else property may burden owners more than it frees them.

The common-law tradition creates a limited right to abandon personal property pursuant to a two-part test. An owner who wishes to abandon her chattel may do so if she forms the subjective intent to relinquish it and also engages in some overt act reflecting that intention. ${ }^{15}$ If you want to get rid of your old couch, for example,

${ }^{11}$ See Johnson, supra note 3.

12 Thomas W. Merrill \& Henry E. Smith, Property: Principles \& Policies 485 ( $2 \mathrm{~d}$ ed. 2012) ("Owner sovereignty is . . commonly thought to include the right to abandon property (throw it away or relinquish all claim to title)[.]").

13 James E. Penner, The Idea of Property in LAw 79 (1997).

${ }^{14}$ Strahilevitz, supra note 7 at 381-82 (discussing Penner's notion of abandonment as rooted in a vision of property as a site of individual autonomy).

15 Ritz v. Selma United Methodist Church, 467 N.W.2d 266 (Iowa 1991); JoHN G. SPRANKLING, UNDERSTANDING PROPERTY LAW § 4.03[B][2], p.38 (4th ed. 2017) 
merely wishing it gone from your living room is not enough. You would need to also engage in some act that a reasonable person would understand as indicating a desire to abandon. This may mean placing the couch on the curb on bulk item trash day or in your front yard with a sign reading "Free." 16 At that point, abandonment is complete; the thing ceases to belong to the owner. Some forms of property, like your unwanted couch, are treated as res derelictae - cast-off resources, free for others to claim as their own exclusive property. ${ }^{17}$ Others, like copyrighted works, become res communes - shared public resources, free for all to use. ${ }^{18}$

Recent work on abandonment characterizes it as a unilateral transfer. ${ }^{19}$ This definition at first blush seems oxymoronic. The nature of transfer is bilateral: sales involve a seller and a buyer; gifts involve a donor and a donee. ${ }^{20}$ While we critique this account below, unilaterality is essential to abandonment. It is different from other forms of alienation precisely because it is a one-sided cession of property rights. The abandoning owner gives up their legal relationship to the thing, but the identity of the subsequent owner-if in fact there ever is one-is not known and is unrelated to the abandoning owner's relinquishment of their rights.

This abstract account of abandonment, though, becomes more complicated in practice. Permitting unfettered abandonment would

("Property is abandoned when the owner (a) intends to relinquish all right, title, and interest in it, but not transfer title to any particular person; and (b) takes action that manifests this intent.").

16 This turns in part on the prevailing norms within the community. In most cities, items unattended on the sidewalk communicate that they are free for taking. A couch placed outside in a college town, however, may not communicate the same message. See Paul Parker, The Couches of Kirkersville, http://parker.sites.truman.edu/thecouches-of-kirksville.

${ }^{17}$ Lauren Benton \& Benjamin Straumann, Acquiring Empire by Law: From Roman Doctrine to Early Modern European Practice, 28 LAW \& HIST. REV. 1, 15 (2010).

See, e.g., Haslem v. Lockwood, 37 Conn. 500, 506-07 (1871). The act of abandonment thus creates a race to determine subsequent ownership via first possession. See Pierson v. Post, 3 Cai. R. 175 (N.Y. 1805).

${ }^{18}$ Carol M. Rose, Romans, Roads, and Romantic Creators: Traditions of Public Property in the Information Age, 66 Law \& Contemp. Probs. 89 (2003); Geer v. State of Conn., 161 U.S. 519, 525 (1896) (referring to res communes as "those things which were common to all belonged no more to one than to the others").

19 Strahilevitz, supra note 7; Peñalver, supra note 7 at 198 ("what distinguishes abandonment as a legal concept ... is that it is a purely unilateral act").

${ }^{20}$ BLACK'S LAW DiCTIONARY (11 th ed. 2019) (defining "transfer" as "a conveyance of property or title from one person to another"). 
impose widespread social costs since unwanted property is likely to have low or even negative value. ${ }^{21}$ Placing your garbage on the curb for pickup complies with local ordinances and does not create an eyesore or a smelly mess for the neighborhood. But placing your old couch in a public park may be less an act of generosity than an attempt to rid yourself of and unwanted and bulky item taking up too much space in your home.

Law thus places a number of constraints on owners who want to abandon their things. Most importantly, abandonment is available at common law only for chattels, not for real property. ${ }^{22}$ Abandoning land can create particularly significant social costs. When underwater owners walked away from homes en masse during the Great Recession, the result was vandalism, squatting, and decay, all of which drove down property values and accelerated economic decline. ${ }^{23}$ And without an owner of record, the state cannot levy and collect taxes on real property. ${ }^{24}$

While blackletter law allows owners to abandon chattel property, this prerogative is subject to a number of legal and practical limits. Local laws designed to prevent owners from externalizing disposal costs often override the common-law freedom to abandon. Trash may be disposed of only on certain days in certain places. In most cities, you would be subject to a municipal citation for dumping your old fax machine on a park bench. And because Floridians tend to

${ }^{21}$ See Strahilevitz, supra note 7 at 372-75 (enumerating the social costs of abandonment). Even Penner acknowledges that the individual's autonomy interest in abandonment must be balanced against non-owners' autonomy interest in not having the costs of owners' abandonment thrust upon them without consent. PENNER, supra note 13, at 79-80 ("[W]hile the interest underpinning property incorporates the interest in getting rid of things on one longer wants, people also have an interest in not being harmed by the way that people deal with their things."). ${ }^{22}$ Pocono Springs Civic Ass'n, Inc. v. MacKenzie, 667 A.2d 233 (Pa. Super. Ct. 1995); SpRANKLING, supra note $15 \S 4.03$ [B][1], p.38 n.9 ("[T]he abandonment doctrine only applies to personal property; real property cannot be abandoned.").

${ }^{23}$ Richard Florida, Vacancy: America's Other Housing Crisis, CiTYLab (July 27, 2018), https://www.citylab.com/equity/2018/07/vacancy-americas-other-housingcrisis/565901; UNITED STATES CONFERENCE OF MAYORS, IMPACT OF THE Mortgage Foreclosure Crisis on Vacant and Abandoned Properties in CitiEs (2010).

${ }^{24} C f$. Merrill \& SMith, supra note 12 at 489 (tracing the prohibition on abandonment of real property to "the incidents and services that landowners were supposed to perform in feudal England, which meant that there could be no gap in the 'seisin' of real property"). 
let their boats float away, either because they grow bored of the salt life or because the watercraft has proven too expensive to maintain, their state passed a law that required watercraft owners to sell their boats or bear their ownership costs. ${ }^{25}$ In light of this, Peñalver argues that abandonment is much more difficult than the common-law rule lets on. ${ }^{26}$ Given the likelihood of municipal fines and the risk of trespass, he regards the right to abandon personalty as "illusory." 27

The blackletter law of abandonment is thus clear in theory but muddled in practice. Owners have a theoretical right to abandon, but a series of limits cabin their ability to do so. These limits derive from reasonable concerns about the social costs of abandoning property. But how do the law and policy of abandonment change when we move from physical property to copyrights?

\section{B. Abandoning Copyrights}

Courts have long articulated the same common-law standard for abandonment of copyrights that applies to corporeal things. ${ }^{28}$ If an owner wants to unilaterally dispossess herself of a copyright, she must form an intention to do so and engage in some overt act reflecting that intent. ${ }^{29}$ The consequences of abandonment, though, are quite different in the copyright context. Abandoned physical things are up for grabs until they are claimed by another owner. By contrast, abandoned copyrighted works instantly become part of the public

${ }^{25}$ State law empowers the Florida Fish and Wildlife Conservation Commission to collect derelict boats and order their owners to reclaim them within five days. Owners who fail to do so are subject to criminal fines and removal costs. FLA. STAT. tit. XL VI, § 823.11(4) (2019). See Peñalver, supra note 7 at 204-05 ("The [Floridian boat] owner cannot disclaim responsibility by saying she has abandoned the boat and that it is, as a result, no longer her concern.").

${ }^{26} I d$. at 202-08.

${ }^{27}$ Id. at 194 ("Viewing the law concerning the right to abandon as a unitary legal structure ... reveals that the owner's right to abandon (even chattels) is largely illusory."').

28 For a full discussion of the history and contemporary status of copyright abandonment case law, see Part III infra.

294 NIMMER ON COPYRIGHT $§ 13.06$ (2019) ("Abandonment occurs only if there is an intent by the copyright proprietor to surrender rights in her work. There is, moreover, strong authority holding that an overt act evidencing such intent is necessary to establish abandonment."); see National Comics Publ'ns, Inc. v. Fawcett Publ'ns, Inc., 191 F.2d 594, 598 (2d Cir. 1951) (L. Hand, J.) (holding that an owner may abandon a copyright, but "must abandon it by some overt act which manifests his purpose to surrender his rights in the work and to allow the public to copy it"). 
domain, available for use by anyone, not just by the first user to stake a claim. ${ }^{30}$

Strahilevitz concludes that, since copyright interests cannot be subsequently reacquired by private owners, copyright abandonment is not abandonment at all. "Copyright 'abandonment' is therefore in some sense an inapt phrase," he writes. "There is no 'roll' of the dice following the abandonment of a copyright-ownership of an abandoned copyrighted work is necessarily public." 31

We recognize that copyright and physical property abandonment are distinct in this respect, but are not convinced that this means that there is no true abandonment of copyrights. For one thing, copyright and physical property abandonment are more alike than different. They are both voluntary relinquishments of ownership rights. They both cause the abandoned thing to be available for anyone to use. Strahilevitz stresses that abandoned copyrights are not "up for

30 Nat'l Comics, 191 F.2d at 598. U.S. trademark law explicitly allows for abandonment. 15 U.S.C. $\S 1127$ (2018) (noting that a mark is abandoned if it becomes generic or "its use has been discontinued with intent not to resume," which may be inferred after three consecutive years of nonuse). In contrast to copyrights, abandoned trademarks become available for others to adopt and establish exclusivity. See Manhattan Industries, Inc. v. Sweater Bee by Banff, Ltd., 627 F.2d 628, 629-630 (2d Cir. 1980) ("Upon the mark's abandonment, a free-for-all ensued.... [and the parties] 'were equally free to attempt to capture the mark to their own use."'); George \& Co. LLC v. Imagination Entm't Ltd., 575 F.3d 383, 400 (4th Cir. 2009) ("Once abandoned, a mark returns to the public domain..."). But see Jorge Contreras, Sui-Genericide (arguing that if a trademark owner abandons its mark by causing it to become a generic term, that market effectively enters the public domain.) Camilla Hrdy and Mark Lemley argue that abandoned trade secrets, like most trademarks, can be claimed by new owners. See Camilla Hrdy \& Mark Lemley, Abandoning Trade Secrets. In light of the novelty requirement, abandoned patentslike copyrights - remain in the public domain. See 35 U.S.C. § 41(b) (2018) (noting that a "patent shall expire" if maintenance fees are not paid within a six month grace period).

${ }^{31}$ Strahilevitz, supra note 7 at 391-92. Peñalver does not consider copyright abandonment, but his understanding of it would apply equally to copyrights and physical chattel property. He defines the essence of abandonment as the "intent to sever one's ties of ownership, not an intent to convey the property to a particular person." Peñalver, supra note 7 at 197. Courts have also tended to define abandonment without insisting on a requirement that the abandoned good be made susceptible of future private ownership. See, e.g., Campbell v. Cochran, 416 A.2d 211, 221 (Del. Super. Ct. 1980) (defining abandoned property as "that to which the owner has voluntarily relinquished all right, title, claim and possession, with the intention of terminating his ownership, but without vesting ownership in any other person, and with the intention of not reclaiming any future rights therein"). 
grabs" in the sense that abandoned physical property is because they cannot be claimed as private property by the next possessor. ${ }^{32}$ Yet abandoned copyrights are in a sense more "up for grabs" than abandoned corporeal things because their public domain status makes them permanently available for anyone to use. ${ }^{33}$

Moreover, the identity of the eventual owner of abandoned property is less important than the intent and conduct of the abandoning owner. Even accepting arguendo the characterization of abandonment as a unilateral transfer, it is effective upon the owner's completion of whatever acts are necessary to perfect cession of their rights, regardless of the eventual disposition of the property. ${ }^{34}$ In the case of both physical chattels and copyrights, the owner forms an intention to give up their rights and then manifests that intent. The post-hoc effect of that decision does not change the owner's intention or its manifestation, so is irrelevant to whether the law recognizes an abandonment. $^{35}$

In light of this, abandonment is not best understood as a transfer at all. The major flaw of the unilateral transfer theory is that it fails to capture the all-too-common situation in which the original owner severs any legal right to the property, but no one claims the abandoned object. As Penalver concedes, even in the absence of a claimant of the res derelictae, abandonment has occurred. Not surprisingly then, characterizing abandonment as unilateral transfer clashes with our intuitions - and law's definitions — of transfer as an

\footnotetext{
${ }^{32}$ Strahilevitz, supra note 7 at 392.

${ }^{33}$ In other jurisdictions, abandonment results in cession to the public. Civil law regimes, such as Poland, France, and Argentina, permit owners to relinquish their rights in real property, at which point it becomes public land, owned and administered by the state. Polish Civil Code., art. 179, § 1; Code Civil [Fr.], art. 713; Código Civil [Arg.], art. 2376, ๆ 1. Brazil holds abandoned land as vacant property whose title passes to the state after ten years. Código Civil [Br.], arts. $589 \S 2,592$. Strahilevitz does acknowledge these regimes, and stresses that they amount to "abandonment in the colloquial sense," though they "do not satisfy [his] narrow definition of abandonment." Strahilevitz, supra note 7 at 394.

${ }^{34} C f$. Peñalver at 198 (observing that abandonment "does not depend on the consent of any third party for its completion").

35 To illustrate the point, if you formed an intent to abandon your fax machine and left it on a park bench with a sign saying, "Free," and then no one took it, it would remain on the bench as res derelictae. But the fact that no one chose to take possession of fax machine would not mean that I had not abandoned it.
} 
act defined by bilaterality. As Blackstone understood, transfer is " $\mathrm{t}] \mathrm{he}$ passing of a thing or of property from one person to another." 36

For copyright in particular, understanding abandonment as a transfer seems particularly implausible. For one thing, valid transfers under the Copyright Act must be reflected in a signed, written agreement. ${ }^{37}$ But when courts evaluate claims of abandonment, they make no effort to ensure compliance with that statutory requirement, ${ }^{38}$ suggesting that they do not regard abandonment as subject to copyright law's transfer rules. ${ }^{39}$

For these reasons, we argue that transfer is not best conceptual model for abandonment. Rather, abandonment should be understood as the relinquishment of a property right. ${ }^{40}$ In contrast to a transfer, abandonment entails relinquishment of property rights by the owner without those rights vesting in another person. This avoids the conceptual contradiction of characterizing unclaimed property as having been transferred to a party who may never materialize. And unlike the transfer theory, this model captures both abandonment that results in res derelictae as well as res communes, giving this account more explanatory leverage. In either case, the owner, through acts that manifest their intent, has voluntarily relinquished their rights in the thing they once owned. Moreover, our theory comports better with intuitions about the essence of abandonment, since it focuses on the owner's choice to sever a legal relationship. Indeed, this is how Black's Law Dictionary defines abandonment: "relinquishing of a right or interest with the intention of never reclaiming it."41

One important consequence for copyright law flows from the recognition of abandonment as a relinquishment or elimination of legal rights rather than a transfer of them. The Copyright Act permits authors and their heirs to terminate copyright transfers and licenses

\footnotetext{
362 BLACKSTONE's COMMENTARIES 291.

${ }^{37}$ Id. 204(a).

${ }^{38}$ See infra Part III.C.

${ }^{39}$ Copyright's statutory definition of "transfer" makes no reference to abandonment. 17 U.S.C. $§ 101$ (2018) (defining “transfer").

${ }^{40}$ Here, we understand "relinquishment" to mean the unilateral relinquishment of ownership. In a different sense, voluntary transfers such as sales or gifts result in the relinquishment of the transferor's rights, but those are obviously not instances of abandonment.

${ }^{41}$ BLACK'S LAW Dictionary (11th ed. 2019).
} 
executed decades prior. ${ }^{42}$ These provisions are designed to give authors an opportunity to renegotiate unfavorable contract terms or regain control over commercially valuable works. To the extent abandonment is understood as a transfer to the public, the termination provisions might suggest that choice could be undone by an author's estate decades later, significantly disrupting expectations about the durability of the public domain. But once we understand abandonment as the relinquishment of rights, there is no transfer to terminate and no opportunity to claw works back from the public domain. ${ }^{43}$

With this conceptual understanding of abandonment and the unique considerations that arise in the copyright context, we turn below to a different set of concerns - namely, the private and social costs of copyright abandonment and the ways in which they shape an owner's decision to relinquish rights.

\section{THE SOCIAL COSTS OF ABANDONMENT}

Beyond its theoretical interest, abandonment has important practical consequences. As a widespread but little appreciated phenomenon, voluntary relinquishment of property rights generates costs and benefits both for owners and for society. This Part explores the social cost calculus of copyright abandonment, contrasting the practice's upsides and downsides with those of abandoning physical property. This account in turn informs the puzzle of copyright abandonment: why would anyone choose to abandon a work of authorship?

\section{A. The Social Costs of Abandoning Physical Property}

It is easy to imagine why owners of physical things may choose to abandon them. Physical property can decay, take up space, require upkeep, and be taxed. As the prevalence of hoarding and the

\footnotetext{
${ }^{42}$ See 17 U.S.C. $§ 203($ a) (2018) ("[T]he exclusive or nonexclusive grant of a transfer or license of copyright or of any right under a copyright, executed by the author on or after January 1, 1978, otherwise than by will, is subject to termination."); id. § 304(c).

${ }^{43}$ One might worry that authors could be coerced in to abandoning their works in much the same way some were pressured to sign unfavorable licenses and assignments. We think this is unlikely since publishers, the parties most likely to exert such pressure, have little to gain by placing works they hope to exploit commercially in the public domain.
} 
success of self-storage facilities illustrate, there are real human costs to having excess stuff. In response, we have witnessed the exploding popularity of Marie Kondo's work promising spiritual peace in giving things away. ${ }^{44}$

In some cases, an owner's unwanted good is more valuable to someone else. In an efficient market, that would lead to a voluntary sale. If you don't want your old couch, and someone else is willing to pay $\$ 25$ for it, that sale will make both of you better off. But you may reasonably conclude that the costs of finding a buyer and engaging in the sale are not worth the effort. If so, abandonment represents an appealing option. You free yourself of an piece of furniture and make it available to someone who may value it more highly, all without the time and trouble of hunting for a willing seller for a low-value transaction. ${ }^{45}$

Abandonment is clearly cost-justified to owners where it represents a simple way to rid themselves of low- or negative-value goods. But abandonment can inflict corresponding social costs. The fax machine might go unclaimed, cluttering the park. Ultimately it may need to be disposed of as garbage at the public's expense. If so, abandonment is little more than a means of taking low- or negativevalue property and making it society's problem. In response, state and local governments have passed laws that regulate or even ban abandonment.

As Strahilevitz highlights, though, a significant number of abandoned goods are of high value and result in value-creating transfers. ${ }^{46}$ People may abandon goods with significant market value if they are associated with a tragedy for the owner, like death or divorce. ${ }^{47}$ Balls hit into the stands at Major League Baseball games are free for whoever manages to lay claim to them, and can be worth many thousands of dollars. ${ }^{48}$ Other modern practices, such as creating digitally-powered treasure hunts via geocaching, provide still more

\footnotetext{
${ }^{44}$ See generally KONDO, supra note 9 (outlining a methodology for de-cluttering one's life as a means to greater well-being).

${ }^{45}$ Giving the fax machine away presents similar transaction costs. $C f$. Strahilevitz, supra note 7 at 370-71 ("Abandonment is advantageous because it enables an owner to rid herself of property while incurring neither the transaction costs of a bilateral transfer nor the decision costs associated with a gift.").

${ }^{46}$ Strahilevitz, supra note 7 at 365-71 (enumerating the examples that follow in this paragraph of abandoned positive-market-value goods).

${ }_{47}$ Id.

${ }^{48}$ Id.
} 
illustrations of the surprising prevalence of abandoning positive-value property. 49

The motivations for these practices vary. An owner may want to abandon goods with powerfully negative personal meaning as the quickest, cheapest means of separating himself from them. MLB likely abandons baseballs hit into the stands because it attracts more fans to games. And people who leave items in geocaches are likely doing so due to a combination of intrinsic enjoyment and reciprocity norms. Even when disclaimed property is socially valuable, though, abandoning it threatens to create costs in the form of confusion about the property's state of title and lawless races to claim it. ${ }^{50}$

The actual practice of abandonment is thus more complicated than a rational-choice analysis would predict. While one would expect abandonment only of low-value goods, owners often abandon even high-value chattels for a variety of self- and other-regarding reasons. This quick summary of the costs, benefits, and reality of physical property abandonment sets the stage for the ensuing discussion of the very different social welfare calculus of abandoning copyrights.

\section{B. The Social Benefits of Abandoning Copyrights}

If the abandonment of physical property benefits owners but results in externalized social costs, the social welfare calculus of copyright abandonment is nearly a mirror image. As we show, abandoning a copyright tends to be costly to owners while generating positive spillovers for society.

\section{Private Welfare Effects}

The work of authorship is an abstraction. Copyright law vests rights in creative expression itself - the work of authorship - separate and apart from the physical medium - books, records, or hard drivesin which that expression is embodied. ${ }^{51}$ Copyright ownership, as currently structured, thus imposes none of the burdens that physical

${ }^{49} \mathrm{Id}$.

${ }^{50} I d$. at 374-75 (discussing confusion and lawless-race costs); see also infra Part II (discussing these ancillary costs in more detail and exploring how they apply to copyright abandonment).

5117 U.S.C. § 202 (2018) (“Ownership of a copyright, or of any of the exclusive rights under a copyright, is distinct from ownership of any material object in which the work is embodied."). 
chattel ownership does. ${ }^{52}$ Works of authorship do not decay; they do not require storage space; and the state does not tax them. In turn, abandoning them does not impose any of the costs associated with physical property: no messy disposal, no risk of cluttering public and private space, no revenue lost by the state. For these reasons, abandonment of copyrights - even economically valueless onescannot be explained in terms of relieving owners of the kinds of costs that physical property ownership may impose. ${ }^{53}$

Copyright abandonment thus seems to bring owners few monetary benefits. It does, however, threaten owners with some obvious costs. Abandoning a copyright means relinquishing forever the ability to extract value from the work by leveraging exclusive rights. In the case of highly valuable works, this could mean bidding farewell to millions of dollars in royalties - which is why we are unlikely to see, for example, J.K. Rowling abandon the rights to Harry Potter. Aside from lost revenue, an owner who abandons their copyright also cedes any ability to prevent uses of the work to which they object. ${ }^{54}$ Matt Furie's infringement lawsuit against Infowars' unauthorized use of Pepe the Frog was inspired not by pecuniary considerations, but by Furie being "dismayed by Pepe's association

\footnotetext{
${ }^{52}$ This is, of course, contingent on the design of the copyright system. Trademarks and patents impose maintenance fees on owners, which abandonment eliminates for owners. Copyright formalities like renewal and registration once imposed similar burdens on copyright holders. We return to forms of architecture that promise to raise the costs of copyright abandonment to an optimal level in Part IV, infra.

${ }^{53}$ Ownership of a work can impose certain cognitive and emotional costs, however. The pressure to review and respond to licensing requests or to police potentially infringing uses require time and energy. Although the loss of control over a work can impose its own burdens. Take, for example, Alan Moore. The author of Watchmen and other massively popular comic books insists on receiving neither credit nor compensation for adaptations of his work. See Adam Epstein, HBO's "Watchmen" Is Great. It's Comic Creator Alan Moore Wants Nothing to Do With It, QUARTZ, Oct. 21, 2019, https://qz.com/quartzy/1732050/why-alan-moore-wantsnothing-to-do-with-hbos-watchmen.

${ }^{54}$ Owners have used their copyrights in this defensive fashion since the inception of the doctrine. See Shyam Balganesh, Censorial Copyright, 73 VAND. L. Rev.

(forthcoming 2020) (tracing the history of censorial uses of copyright to the early 1700 s). Scholars disagree about whether this practice is socially valuable. Compare Balganesh, Censorial Copyright (advancing a limited defense of censorial copyright) with John Tehranian, The New Censorship, 101 IowA L. REV. 245 (2015) (broadly criticizing censorial copyright).
} 


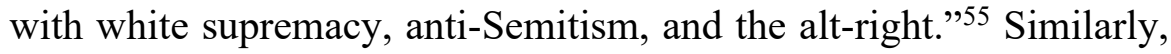
Carol Highsmith, after donating tens of thousands of photographs to the Library of Congress, sued Getty Images after the company charged for licenses to use the images and failed to properly credit her. ${ }^{56}$

Of course, most copyrighted works earn little or no revenue. Those that are valuable tend to have short economic lifespans, accruing all of their revenue within a decade or so. ${ }^{57}$ Even so, owners may decline to give up their rights on the off-chance that they may start earning again later in life. Nicholas Taleb coined the phrase "black swan" for a low-probability, high-impact negative event, like the housing market crash of $2008 .^{58}$ But there are also "golden swans"-low-probability, high-impact positive events such as winning the lottery. Copyright holders may hang on to an unprofitable work because they hope for such an unlikely event. While rare, golden swans are not unheard of. James Kennedy Toole found no publishers for his comic novel A Confederacy of Dunces for decades, eventually taking his life in part over the manuscript's apparent failure. Only following his death did his mother finally get the book published, when it became a modern classic and commercial success. ${ }^{59}$

Various cognitive biases exacerbate copyright owners' tendencies to retain ownership of works that appear largely worthless. Optimism bias causes us to overestimate the chances of good outcomes. ${ }^{60}$ This is why lottery tickets sell so well. Related, the

\footnotetext{
${ }^{55}$ Bret Barrouquere, Creator of Pepe the Frog Gets Trial Date in Case Against Alex Jones, SPLCENTER.ORG (Sept. 13, 2018), available at https://www.splcenter.org/hatewatch/2018/09/13/creator-pepe-frog-gets-trial-datecase-against-alex-jones.

56 First Amended Complaint, Highsmith v. Getty Images, No. 16-cv-05924 (S.D.N.Y.).

${ }^{57}$ Kristelia Garcia \& Justin McCrary, A Reconsideration of Copyright's Term, 71 ALA. L. REV. 351, 383 (2019) ("[M]ost information goods earn the majority of all the revenue that they are ever going to earn in the first five to ten years following their release[.]").

${ }^{58}$ Nicholas Taleb, The Black Swan: The Impact of the Highly Improbable xxii (2d ed. 2010) (defining a black swan event as possessing "rarity, extreme impact, and retrospective predictability").

${ }^{59}$ Karl Miller, An American Tragedy, New Statesman America, Mar. 5, 1999, available at https://www.newstatesman.com/node/148778 (recounting the life and death of O'Toole and the posthumous success of A Confederacy of Dunces)

${ }^{60}$ Christine Jolls \& Cass Sunstein, Debiasing Through Law, 35 J. Legal STUD. 199, 204 (2006) ("Optimism bias refers to the tendency of people to believe that their own probability of facing a bad outcome is actually lower than it is.").
} 
endowment effect causes us to overvalue things we own relative to fair market value. ${ }^{61}$ Thus copyright owners of economically inert works may rate their appeal far higher than the zero value the work would actually fetch in open exchange. ${ }^{62}$ Such owners would be unwilling to abandon their works, believing against all evidence that a seller will eventually pay them some inflated price.

The private welfare calculus of copyright abandonment is the polar opposite of abandonment of physical chattels. Abandonment of physical assets flourishes, and must be restrained by law, because it tends to benefit owners by allowing them to offload the costs of lowor negative-value property. By contrast, abandoning a copyright seems to be all downside for an owner. Abandonment sacrifices the ability to profit from or control a work, while gaining nothing since a copyright imposes no maintenance costs. ${ }^{63}$ That asymmetry holds for the public welfare effects of copyright and physical property abandonment as well.

\section{Public Welfare Effects}

Compared to physical property, copyright abandonment offers greater promise for creating social value. For one thing, abandoned works do not become privately owned by the next taker, but enter the public domain. ${ }^{64}$ Expressive works are, by nature, public goods; they are both nonrivalrous and nonexcludable. By limiting their

${ }^{61}$ Daniel Kahneman, Jack L. Knetsch, \& Richard Thaler, Experimental Tests of the Endowment Effect and the Coase Theorem, in BEHAVIORAL LAW AND ECONOMICS 211, 213 (Cass Sunstein, ed.) (describing and illustrating the endowment effect, and describing it as a manifestation of loss aversion).

${ }^{62}$ See Christopher Buccafusco \& Christopher Jon Sprigman, Valuing Intellectual Property: An Experiment, 91 CORNELl L. Rev. 26 (2010).

${ }^{63}$ As discussed below, there are non-pecuniary interests that may-and domotivate some owners to abandon their works. See infra Part II.C. But from the strictly pecuniary perspective that typifies copyright policy, owners rarely have incentives to abandon. Christopher Buccafusco \& David Fagundes, The Moral Psychology of Copyright Infringement, 100 MINN. L. REV. 2433, 2438-44 (2016) (describing copyright's focus on pecuniary interests to the exclusion of nonpecuniary ones).

${ }^{64}$ The "public domain" is a term with a number of overlapping and sometimes competing definitions. Pamela Samuelson, Enriching Discourse on Public Domains, 55 Duke L.J. 783 (2006). Our definition most closely resembles Samuelson's Public Domain 1, with the exception that we limit our discussion to copyright, to the exclusion of other regimes that may impose limitations on the use of such works. 
reproduction and use, copyright law seeks to convert them to private goods. Abandonment, by contrast, strips away that artificial scarcity. As a result, abandoning a work generates utility for the thousands or even millions of people who can now freely access and use it. ${ }^{65}$

Related, abandonment promotes the distinctive normative aims of copyright law: increasing public access to information goods. For utilitarians, at least, the goal of any body of law is to maximize social welfare. ${ }^{66}$ In the context of real and chattel property, law tends to achieve this end by facilitating the highest-value uses of land and goods by private owners. ${ }^{67}$ Copyright, by contrast, seeks to maximize social value not only by enriching the owners of works. Rather, the ultimate aim of copyright law is to enrich the public by incentivizing the production of creative and informative works of authorship. ${ }^{68}$ By encouraging the creation of works by means of a shorter-term monopoly, ${ }^{69}$ the longer-term goal is to provide the public with access

65 Abandonment can also reduce information costs associated with copyright ownership. Given the divisibility and transferability of copyright interests, identifying the owner of a work is often difficult. Transfers of copyright ownership are generally not recorded, complicating efforts to track rights holders over time. These difficulties contribute to the orphan works problem - the inability to identify or locate copyright holders, hampering efforts to license those works. Since abandonment is irrevocable, it cuts off the possibility of future assignments and exclusive licenses. And since it requires some clear evidence of the intent to abandon, users are more likely to have notice of the work's public domain status. Additionally, abandonment can clarify the status of works of questionable copyright eligibility.

66 See Richard Layard, Happiness: Lessons From A New SCIENCE 4-5 (2005) (summarizing Bentham's views on utilitarianism as a preference for choices that tend to maximize the welfare ("greatest happiness") of all affected persons).

${ }^{67}$ Cf. Harold Demsetz, Toward a Theory of Property Rights, 57 AM. ECON. REv. 347 (1967) (arguing that property rights emerge in order to allow owners to internalize as much value as possible from the exploitation of their res).

${ }^{68}$ Sony Corp. of Am., Inc. v. Universal City Studios, Inc., 464 U.S. 417, 429 (1984) ("The monopoly privileges that Congress may authorize are neither unlimited nor primarily designed to provide a special private benefit. Rather, the limited grant is a means by which an important public purpose can be achieved.").

${ }^{69}$ Of course, copyright terms are no longer "shorter-term" by any reasonable definition. On the contrary, consensus has emerged that their current length-life of the author plus seventy years, see 17 U.S.C. $\S 303$, is far too long. E.g., Linda Cohen \& Roger Noll, Intellectual Property, Antitrust, and the New Economy, 62 U. PITT. L. REV. 453, 471 (2001) ("[N]o plausible incentive rationale exists for this incredibly long duration."). 
to a richer array of information goods. ${ }^{70}$ This aspiration is rooted in the Constitution, which confers on Congress the power to create "exclusive rights" only for "limited times" and for the purpose of "promoting the progress of science." 71 In this scheme, owners' rights are only a means to an end, extended as an incentive only as minimally necessary to encourage the creation of such works. ${ }^{72}$

But the case for the public domain is not merely a matter of commitment to abstract principles. The public domain has practical, measurable effects on consumer welfare and creativity. ${ }^{73}$ First, as Paul Heald has demonstrated, public domain works are often more widely available than their copyrighted counterparts. ${ }^{74}$ Moreover, public domain works - since they can be offered by a variety of competing publishers without compensation to rights holders - are generally less expensive. ${ }^{75}$ Beyond promoting access, the public domain facilitates new creative production "by leaving the raw material of authorship available for authors to use." 76 Derivative works based on public domain materials are a substantial component of the copyright market. In the film industry for example, recent years have seen multiple

\footnotetext{
${ }^{70}$ This is the "incentive/access paradigm" that numerous scholars have invoked as the central framework for understanding copyright. E.g., Jonathan M. Barnett, 157 U. PA. L. REV. 1691, 1693 (2009) (calling the "incentives/access tradeoff ... the familiar foundation for normative discussions about the desirable scope of intellectual property"). Scholars have called striking the proper balance between incentives and access "the central problem in copyright law." William Landes \& Richard Posner, An Economic Analysis of Copyright Law, 18 J. LEGAL STUD. 325, 326 (1989).

${ }^{71}$ U.S. CONST. art. I, $\S 8$, cl. 8. At the time of the Framing, "science" was understood to extend to creative and informative works. See Malla Pollack, What Is Congress Supposed to Promote?: Defining "Progress" in Article I, Section 8, Clause 8 of the United States Constitution, or Introducing the Progress Clause, 80 NeB. L. REV. (2001); but see Ned Snow, The Meaning of Science in the Copyright Clause, 2013 BYU L. REV. 259 (arguing that the original meaning of "science" was more narrow and excluded speech unprotected by the First Amendment).

72 See United States v. Paramount Pictures, Inc., 334 U.S. 131, 158 (1948) ("The copyright law, like the patent statutes, makes reward to the owner a secondary consideration.").

${ }^{73}$ See generally GLYNn LunNeY, COPYRIGHT's EXCESS (2019).

${ }^{74}$ Paul J. Heald, How Copyright Keeps Works Disappeared, 11 J. EMPIRICAL LEgaL STUD. 829 (2014); Paul J. Heald, Property Rights and the Efficient Exploitation of Copyrighted Works: An Empirical Analysis of Public Domain and Copyrighted Fiction Bestsellers, 92 MinN. L. REV. 1031 (2008).

${ }^{75} \mathrm{Id}$.

${ }^{76}$ Jessica Litman, The Public Domain, 39 EMORY L.J. 965 (1990).
} 
adaptations of Alice in Wonderland, Peter Pan, The Jungle Book, Sherlock Holmes, King Arthur, and Robin Hood, among others. ${ }^{77}$

Some critics have argued that abandonment could result in wasteful overuse of public domain works. Posner and Landes argue that the owners of works act as stewards, controlling and limiting their use to make sure that the work is not cheapened by low-quality exploitation. ${ }^{78}$ But recent scholarship suggests just the opposite. Studies have shown that the effect of private ownership on creative production is at best indeterminate, and possibly even negative. ${ }^{79}$ The bulk of the evidence seems to indicate that innovation and creativity thrive when works are free, not when they are subject to exclusive rights. ${ }^{80}$ Other research shows in particular that entering the public domain does not cause works to disappear. To the contrary, Chris Buccafusco and Paul Heald have shown that public domain works are commercialized at a higher rate than copyrighted ones, and at a similar level of quality. ${ }^{81}$ Moreover, we should expect reduced market demand to discipline producers of derivatives based on over-exploited public domain works. If studios produce too many Robin Hood films, for example, declining revenue would make future Robin Hood sequels and reboots less likely. On the whole, abandonment should

77 See List of Modernized Adaptations of Old Works, WIKIPEDIA https://en.wikipedia.org/wiki/List_of_modernized_adaptations_of_old_works.

78 William LANDES \& Richard POSNER, THE ECONOMIC STRUCTURE OF INTELLECTUAL PROPERTY LAW 213 ("[A]1l valuable resources, including copyrightable works, should be owned, in order to create incentives for their efficient exploitation and to avoid overuse."). Landes \& Posner's argument was rooted in Hardin's Tragedy of the Commons, which has since been discredited as descriptively inaccurate and rooted in the author's eugenicist beliefs. See Matto Mildenberger, The Tragedy of The Tragedy of the Commons, ScI. AM., Apr. 23, 2019, available at https://blogs.scientificamerican.com/voices/the-tragedy-of-thetragedy-of-the-commons/.

${ }^{79}$ See generally Eric E. Johnson, Intellectual Property and the Incentive Fallacy, 39 Fla. St. U. L. Rev. 623 (2012) (citing and summarizing this literature).

${ }^{80}$ See, e.g., Rebecca Tushnet, Economies of Desire: Fair Use and Marketplace Assumptions, 51 Wm. \& Mary L. Rev. 513, 528-32 (2009) ("The desire to create can be excessive, beyond rationality, and free from the need for economic incentive. Psychological and social concepts can do more to explain the creative impulses than classical economics. [A] copyright law that treats creativity as a product of incentives can miss the mark and harm what it aims to promote.").

${ }^{81}$ Christopher Buccafusco \& Paul Heald, Do Bad Things Happen When Works Fall Into the Public Domain? Empirical Tests of Copyright Term Extension, 28 BERKELEY J.L. \& TECH. 1 (2013). 
translate to greater commercialization and accessibility, thereby advancing copyright's core aspirations.

The public welfare benefits of abandonment are particularly salient given the long history of owner-friendly legal reforms that expanded the temporal and substantive breadth of copyrights, radically reducing the scope of the public domain. Historically, works have entered the public domain in five ways. First, works ineligible for copyright protection - those that exhibit insufficient originality or useful articles with inseparable pictorial or graphical elements, for example - are part of the public domain ab initio. Second, works enter the public domain at the expiration of their copyright term. ${ }^{82}$ Third, under the pre-1978 dual-term regimes, works entered the public domain when copyright holders neglected to renew. Fourth, the failure to comply with formal requirements of copyright- notice and, less commonly, deposit-resulted in forfeiture of copyright. Finally, intentional abandonment of copyright can dedicate works to the public domain.

Aside from abandonment, each of these mechanisms for building the public domain has faced considerable legislative and judicial limitations. The congressional expansion of copyright to new categories of works - sound recordings, ${ }^{83}$ software, ${ }^{84}$ architecture, ${ }^{85}$ to name a few recent examples - and the arguable embrace of previously ineligible useful articles by the Supreme Court in Star Athletica ${ }^{86}$ have reduced the public domain. A series of copyright term extensions, beginning in $1831^{87}$ and culminating in the Copyright Term Extension Act in $1998,{ }^{88}$ have slowed the flow of works into the public domain to a trickle. Until 2019, no works had joined the U.S. public domain through this mechanism for two decades. And no works created under the current statute will enter the public domain until the end of 2048,

\footnotetext{
8217 U.S.C. $\$ 302$ (2018).

${ }^{83}$ Act of October 15, 1971, Pub. L. No. 92-140, 92d Cong., 1st Sess., 85 Stat. 391.

${ }^{84}$ Computer Software Copyright Act of 1980, Pub. L. No. 96-517, 94 Stat. 3015, 3028 (1980).

${ }^{85}$ Architectural Works Copyright Protection Act, Pub. L. No. 101-650, 104 Stat. 5089 (1990).

${ }^{86}$ Star Athletica, LLC v. Varsity Brands, Inc., 580 U.S. (2017).

${ }^{87}$ Copyright Act of 1831, 4 Stat. 436.

${ }^{88}$ Copyright Term Extension Act, Pub. L. 105-298, §102(b) and (d), 112 Stat. $2827-2828$
} 
at the earliest. ${ }^{89}$ Moreover, renewal failures were reasonably common until the 1976 Act adopted the current unitary term of protection. ${ }^{90}$ But that shift removed the opt-in character of the second half of copyright terms, thereby eliminating a simple mechanism for sorting works of low perceived value into the public domain. ${ }^{91}$ And perhaps most importantly, neither the notice nor the deposit requirements carry the risk of forfeiture today. ${ }^{92}$ As a result of the shift from a system in which copyright required authors to opt-in to one in which copyrights vest automatically upon fixation, ${ }^{93}$ trillions of works that would have otherwise been part of the public domain are instead subject to copyright. ${ }^{94}$ The Uruguay Round Agreements Act of 1994 even created, for the first time, a mechanism by which parties could restore the copyrights in works that had reached the public domain. ${ }^{95}$ And even when works are unquestionably in the public domain, litigants and would-be rightsholders have found ways to impose limitations on

${ }^{89}$ Assuming an author created a work on Jan. 1, 1978 and died that same day, copyright would persist for an additional 70 years. 17 U.S.C. $§ 302$ (2018).

${ }^{90}$ Zvi S. Rosen \& Richard Schwinn, An Empirical Study of 225 Years of Copyright Registrations, TUlane L. REV. (forthcoming), https://ssrn.com/abstract=2643075 (calculating a renewal rate for all U.S. copyrighted works ranging from roughly $10 \%$ to $20 \%$ throughout the twentieth century)Sean Redmond, U.S. Copyright History 1923-1964, New York PUbliC Library, May 31, 2019, https://www.nypl.org/blog/2019/05/31/us-copyright-history-1923-1964; (reporting a renewal rate of toughly $25 \%$ for books from 1923-1964).

${ }^{91}$ Christopher Sprigman, Reform(aliz)ing Copyright, 57 StAN. L. REV. 485, 498 (2004) (pointing out that with bifurcated terms, owners of lower-value works would decline to file for renewal, causing those works to enter the public domain after 28 years).

${ }_{92}$ See Berne Convention Implementation Act of 1988, Pub. L. No.100-568, 102 Sta. 2853 (1988).

${ }^{93} \mathrm{Id}$.

${ }^{94}$ In 2018 alone, an estimated 1.2 trillion photos were taken worldwide. Caroline Cakebread, People will take 1.2 trillion digital photos this year-thanks to smartphones, BUSINESS INSIDER (Aug. 31, 2017), https://www.businessinsider.com/12-trillion-photos-to-be-taken-in-2017-thanks-tosmartphones-chart-2017-8. And nearly 300 billion emails are sent every day. Heinz Tschabitscher, The Number of Emails Sent Per Day in 2019 (and 20+ Other Email Facts), LiFEWIRE (Jan. 3, 2019), https://www.lifewire.com/how-many-emails-aresent-every-day-1171210.

9518 U.S.C. § 2319A (2018) (allowing restoration of copyright for works by foreign authors that had fallen into the public domain for failure to comply with pre-1976 Act statutory formalities); see Golan v. Gonzales, 565 U.S. 302 (2012) (affirming constitutionality of URAA's copyright restoration provisions). 
their use. ${ }^{96}$ Given these restraints, abandonment remains one of the few means to funnel works into the public domain.

Today, copyright terms regularly extend for well over a hundred years. But abandonment can render a work free for common use well in advance of the statutory term. And because abandonment reflects an owner's choice to cede rights in their work, it allows owners themselves to determine the proper length of their exclusive rights. ${ }^{97}$

In this sense, abandonment shares some traits with permissive licenses like those provided by Creative Commons. Those licenses give copyright holders the option to free their works from some of the restrictions normally imposed by copyright law, facilitating uses by the public without requiring cumbersome negotiations for each and every use. Both abandonment and permissive licensing offer paths for creators who prefer to forego some measure of their statutory copyright entitlements.

But abandonment and Creative Commons licenses play related but distinct roles in the copyright system. Abandonment works a complete and total transfer to the public domain, while permissive licensing helps copyright holders to permit some uses while forbidding others. That basic operational distinction gives rise to two important differences between abandonment and permissive licensing.

First, abandonment is irrevocable. It results in public domain status and the destruction of any exclusive rights in the work. The former owner has no legal mechanism for reclaiming a copyright once

\footnotetext{
${ }^{96}$ See Elizabeth Rosenblatt, The Adventure of the Shrinking Public Domain, $86 \mathrm{U}$. Colo. L. ReV. 561 (2015); Warner Bros. V. X One X Prods., 644 F.3d 584 (8th Cir. 2011).

${ }^{97}$ If an owner feels that $\$ 20,000$ suffices as fair reward for her work, and she extracts that amount from a work within ten years, then she can abandon it then and allow the public free access to it without sacrificing any incentive effects. By contrast, the current copyright term - life of the author plus 70 years - is at best a crude approximation of the lifespan of an author's heirs, and is untethered to any notion of optimal incentives. A group of prominent economists signed on to an amicus brief in Eldred v. Ashcroft, the Supreme Court case challenging the constitutionality of copyright term extension. They concluded that "it is highly unlikely that the economic benefits from copyright [term] extension ... outweigh the additional costs." Brief of George A. Akerlof et al., In re Eldred v. Ashcroft (May 20, 2002) at 3. Of course, many works were not created due to any incentive effects, such as emails, cell phone photos, and even some art and literature. Authors unconcerned about royalties or control should be willing to cede their works to the public domain at zero cost-if they had a simple way to do so.
} 
abandoned. ${ }^{98}$ Creative Commons licenses are, by their own terms, irrevocable. ${ }^{99}$ There are at least two considerations that cast doubt on this insistence, however. For one thing, copyright licenses are generally revocable in the absence of consideration. ${ }^{100}$ As bare grants of permission, the Creative Commons licenses likely lack the sort of consideration that would prompt a court to treat their irrevocability as a binding contractual term. Even if $\mathrm{CC}$ licenses are not revocable at will, they are likely subject to the Copyright Act's termination of transfer provisions, which extend to both exclusive and nonexclusive licenses. ${ }^{101}$ Nor does the language describing the CC license as "irrevocable" warrant a different conclusion, since statutory termination of transfer operates regardless of license terms to the contrary. ${ }^{102}$ Abandonment, for better or worse, is permanent in a way no license can be. ${ }^{103}$

The second difference between abandonment and permissive licenses relates to information costs. ${ }^{104}$ Creative Commons licenses,

${ }^{98}$ See supra I.B.

99 See, e.g., Attribution 4.0 International, CREATIVE COMmONS, https://creativecommons.org/licenses/by/4.0/legalcode "Subject to the terms and conditions of this Public License, the Licensor hereby grants You a worldwide, royalty-free, non-sublicensable, non-exclusive, irrevocable license to exercise the Licensed Rights in the Licensed Material.").

${ }^{100}$ Generally, nonexclusive licenses are revocable in the absence of consideration. Avtec Sys. Inc. v. Peiffer, 21 F.3d 568, 574 n. 12 (4th Cir.1994) ( "an implied license is necessarily nonexclusive and revocable absent consideration"); Keane Dealer Servs., Inc. v. Harts, 968 F.Supp. 944, 947 (S.D.N.Y.1997) ("If no consideration was given, the license was revocable, and the institution of this lawsuit would constitute revocation.”); Johnson v. Jones, 885 F.Supp. 1008, 1013 n. 6 (E.D.Mich.1995); see also 3 NiMMER ON COPYRIGHT, § 10.02(B)(5).

A license that is irrevocable on its own terms will be treated as such only when it is incorporated into an otherwise enforceable contract. See State St. Glob. Advisors Tr. Co. v. Visbal, No. 1:19-CV-01719-GHW, $2020 \mathrm{WL} 71162$, at *23 (S.D.N.Y. Jan. 3, 2020) ("the Copyright License Agreement states that the license is irrevocable. An irrevocable license is '[i]mpossible to retract or revoke.') (quoting Nano-Proprietary, Inc. v. Canon, Inc., 537 F.3d 394, 400 (5th Cir. 2008)).

10117 U.S.C. $\S 203$ (a) (2018) ("[T]he exclusive or nonexclusive grant of a transfer or license of copyright or of any right under a copyright, executed by the author on or after January 1, 1978, otherwise than by will, is subject to termination.”).

${ }^{102} I d$. at $\S 203(\mathrm{a})(5)$.

${ }^{103}$ Lydia Loren has argued that Creative Commons licenses should be understood as a partial abandonment of copyright as a means of increasing their reliability and durability. See Loren, supra note 6 at_325-7.

${ }^{104}$ Open licensing regimes entail a range of transaction costs. These include initial review of works and their license terms, due diligence for mergers and acquisitions, 
for example, allow licensors some measure of choice in how their works can be used. They permit licensors to allow or disallow commercial uses and derivative works, for example. ${ }^{105}$ That flexibility comes at the cost of ambiguity, however. How do users know whether a use is commercial? ${ }^{106}$ How do they distinguish between derivatives and mere reproductions?

IBM recently came under for fire for using nearly a million CC-licensed images harvested from Flickr as training data for facial recognition research. ${ }^{107}$ Many copyright holders were outraged by this unexpected use of their images, prompting Creative Commons to issue a statement ${ }^{108}$ and update its frequently asked questions to address the intersection of CC-licensed works and AI. ${ }^{109}$ For licensors who permitted commercial use, IBM's facial recognition system revealed potential unintended and unforeseen consequences. And for those who limited their works to noncommercial use, it highlighted the ambiguity of CC license terms as applied to early stage research. The simplicity of abandonment would again prevent either outcome. Works dedicated to the public domain are available for all to use, with no exceptions or restrictions.

Software provides another case study in the challenges that permissive licenses sometimes create. Early software developers

and management of internal use and external distribution of open-licensed materials. See Clark D. Asay, A Case for the Public Domain, 74 OHIo St. L.J. 753, 768-775 (2013).

105 About the Licenses, CREATIVE COMMONS, https://creativecommons.org/licenses

106 The question of the scope of the Creative Commons non-commercial license has been litigated at least twice. See Great Minds v. Fedex Office \& Print Servs., Inc., 886 F.3d 91, 97 (2d Cir. 2018) (holding that licensees can rely on third parties, including commercial copy shops, to exercise their rights under the license); Great Minds v. Office Depot, Inc., No. 18-55331, 2019 WL 7206433, at*4 (9th Cir. Dec. 27, 2019) (same).

${ }^{107}$ Erik Carter, Facial recognition's 'dirty little secret': Millions of online photos scraped without consent, NBC NEWS, (MAR. 12, 2019, 3:32 AM), https://www.nbcnews.com/tech/internet/facial-recognition-s-dirty-little-secretmillions-online-photos-scraped-n981921

108 Ryan Merkley, Use and Fair Use: Statement on shared images in facial recognition AI, CREATIVE COMMONS (Mar. 13, 2019), https:/creativecommons.org/2019/03/13/statement-on-shared-images-in-facialrecognition-ai/

109 Artificial intelligence and CC licenses, CREATIVE COMMONS, https://creativecommons.org/faq/\#artificial-intelligence-and-cc-licenses 
pioneered permissive licensing, ${ }^{110}$ but the licenses they rely on do not always clearly reflect their intentions. Sometimes developers adopt licenses they incorrectly believe dedicate their contributions to the public domain; other times developers who likely dedicated their works to the public domain distribute them with copyright. ${ }^{111}$ These misunderstandings about the practical impact of permissive licenses are widespread. Indeed, Clark Asay has argued that the chief reason abandonment is not more common among software developers, despite their apparent desire to dedicate works to the public, is the lack of clarity surrounding license terms. ${ }^{112}$ A regime that provided owners a clear pathway to abandonment would avoid this ambiguity. ${ }^{113}$

Some massively successful software projects have been released under generous permissive licenses, suggesting that abandonment may appeal to such developers as well. ${ }^{114}$ But even if former blockbusters are unlikely to be abandoned, a functioning abandonment doctrine can still enrich the public domain substantially.

\footnotetext{
${ }^{110}$ See Sapna Kumar, Enforcing the GNU GPL, 2006 U. Ill. J. L. Tech. \& Pol'y 1, 8-9 (dating the origin of copyleft licenses to the late 1980s and the work of Richard Stallman); Asay, supra note 104.

${ }^{111} I d$. at $791 \mathrm{n} .213$ (recounting these examples).

${ }^{112} \mathrm{Id}$. at 790. Even users of such software of sometimes dissuaded by the risk associated with unclear license terms. $I d$. at 785 .

${ }^{113}$ Even the Library of Congress makes uses ambiguous language when it makes works it has acquired freely available to the public to "use and reuse." Free to Use and Reuse Sets, LIBRARY OF CONGRESS, https://www.loc.gov/free-to-use. For example, the Library "purchased the intellectual property rights" for the John Margolies Roadside America Photograph Archive, which comprises some 11,000 photos taken over 40 years. Wendi Maloney, Free to Use and Reuse: John Margolies Photographs of Roadside America, LIBRARY OF CONGRESS, July 6, 2017, https://blogs.loc.gov/loc/2017/07/free-to-use-and-reuse-john-margolies-

photographs-of-roadside-america. According to the Library, since it owns the rights to the photos, "there are no known copyright restrictions on the photographs." John Margolies Roadside America Photograph Archive, LIBRARY OF CONGRESS, https://www.loc.gov/rr/print/res/723_marg.html. We think this statement is likely insufficient evidence of intent to abandon, suggesting that the Library of Congress itself lacks sufficient guidance for eliminating copyright restrictions on works it promotes for free public use.

${ }^{114}$ About 250 million people use Firefox, the web browser distributed under the permissive Mozilla Public License. See Firefox Public Data Report, https://ata.firefox.com/dashboard/user-activity. And the Apache HTTP Server, distributed under the eponymous license, serves more than 300 million websites. January $2020 \quad$ Web Server Survey, NETCRAFT, https://news.netcraft.com/archives/category/web-server-survey.
} 
Thanks to the low standards of the 1976 Act, ${ }^{115}$ copyright inheres in all manner of works that appear to have minimal freestanding commercial value: your last email to a co-worker, that photo you hastily took on your phone, even this article. Of course, few are counting down the days until the smartphone photo you took of your lunch last week is free from copyright, and some might question the merit of adding a raft of similarly low-value works to the public domain.

But works that have little value standing alone may have considerable value in the aggregate. As technology develops, new uses of works may emerge that leverage a more extensive public domain. As Google's efforts to index images and scan books demonstrates, a searchable corpus of individual works has value greater than the sum of its parts. Although both of those programs were ultimately endorsed as fair uses, they were limited in ways that lessened their social utility. Google Image Search offers access to thumbnail images, not full resolution originals, and Google Books provides users snippets of copyrighted books in the absence of a license. Public domain books, in contrast, can be viewed in full and used without restriction. ${ }^{116}$ And while successful assertions of fair use can secure some of the same benefits of abandonment, such assertions are often expensive and risky. Established firms like Google can expend the resources necessary to test a novel fair use theory. But abandonment offers greater clarity ex ante, favoring smaller actors.

Artificial intelligence training data presents another compelling case for a public domain reinvigorated with works that may appear to have little standalone value. For better or worse, artificial intelligence promises to shift decision-making from humans to automated systems they design. From banking, ${ }^{117}$ to driving, ${ }^{118}$ to

\footnotetext{
${ }^{115}$ All that is required for copyright to vest in a work of authorship is fixation of an original work in a tangible medium of expression. 17 U.S.C. § 102(a) (2018).

116 The Library Project - Books Help, GOOGLE, https://books.google.com/googlebooks/library/index.html.

117 Ted Greenwald, How AI Is Transforming the Workplace, WALL St. J. (Mar. 10, 2017), https://www.wsj.com/articles/how-ai-is-transforming-the-workplace1489371060.

${ }^{118}$ Sigal Samuel, A new study finds a potential risk with self-driving cars: failure to detect dark-skinned pedestrians, Vox, (Mar. 6, 2019), https://www.vox.com/futureperfect/2019/3/5/18251924/self-driving-car-racial-bias-study-autonomous-vehicledark-skin.
} 
writing pop music, ${ }^{119}$ AI systems will play an increasingly important role in our lives. Many AI systems "learn" to make decisions by processing massive collections of human-created texts, images, and recordings. As Amanda Levendowski has argued, copyright law has contributed to the biases AI systems exhibit by steering developers towards particular sorts of training data. ${ }^{120}$

AI developers, for example, have made repeated use of the collection of 600,000 emails sent between Enron employees because of their perceived public domain status and the low legal risk associated with their use. ${ }^{121}$ Training AI how to write and think using the emails of employees of a company engaged in massive fraud presents obvious problems. But as Levendowski notes, existing public domain works embed their own potential biases. The bulk of the public domain comprises works published before 1924-works written predominantly by wealthy white men, reflecting the prejudices and assumptions of their era. ${ }^{122} \mathrm{~A}$ public domain populated by contemporary works, even those with little independent commercial value, would better reflect the values and composition of society.

In addition, such a reinvigorated public domain could significantly reduce the transaction costs introduced by automatic copyright protection. Creators of all sizes, from independent documentarians and university presses to Hollywood studios and massive trade publishers, expend considerable time and effort in clearing often incidental uses of copyrighted material. This clearance process is frustrated by fractured rights, orphan works, and other practical hurdles. ${ }^{123}$ As a result, transaction costs can frustrate otherwise mutually-desirable licenses. ${ }^{124}$ But since nearly every photo or piece of music created in the last forty years is protected by copyright, the cost of clearance is one creators and distributors must

\footnotetext{
119 Bartu Kaleagasi, A New AI Can Write Music as Well as a Human Composer, FUTURISM (Mar. 9, 2017), https://futurism.com/a-new-ai-can-write-music-as-wellas-a-human-composer.

${ }^{120}$ Amanda Levendowski, How Copyright Law Can Fix Artificial Intelligence's Implicit Bias Problem, 93 WASH. L. ReV. 579 (2018). There is, of course, no guarantee that abandoned works would not introduce their own biases. But increased availability of public domain training data would tend alleviate these concerns on the whole.

${ }^{121} \mathrm{Id}$.

${ }^{122} \mathrm{Id}$.

123 See United States Copyright Office, Orphan Works and Mass DigitiZATION 105 (2015).

${ }^{124} I d$.
} 
bear. Creative Commons licenses have significantly reduced those costs by communicating a set of permissions for subsequent users that do not require further negotiation. But those permissions are not always sufficient and sometimes introduce ambiguity that militates in favor of an explicit license. Abandonment, on the other hand, simplifies the status of a work and eliminates the need for clearance costs.

Abandonment of copyrighted works also avoids the social costs typically associated with the abandonment of physical property. Abandoned things create high disposal costs for society. But since works of authorship have no physical existence, they do not threaten to create clutter. Strahilevitz also shows that abandoned goods threaten costly races to claim title. But since abandoned copyrights become part of the public domain, free for all to use, there is no need to rush to become their next owner. Finally, Strahilevitz raises the concern that the presence of abandoned goods creates confusion about who owns things, and whether they are owned at all. This concern is relevant for copyright, which is already dogged by confusion about the ownership of works. Abandonment could make ascertaining title even more complex for some works. But a properly administered abandonment doctrine would reduce those information costs by clearly communicating the public domain status of works. ${ }^{125}$

It is also worth questioning the assumption that owners will abandon only low- or zero-value works. Strahilevitz has shown that abandonment of higher-value physical property is surprisingly common. As we detail below, much the same is true for information goods, where creators often aspire to place their works into the public domain.

\section{Revealed Preferences \& Attempted Abandonment}

The social cost calculus of abandoning copyrights is the polar opposite of the social cost calculus of abandoning physical property. Abandoning physical property tends to benefit owners while shifting costs onto society, allowing owners to externalize the costs of low- or negative-value property. By contrast, abandoning copyrights can be costly for owners but beneficial for the public. It provides a means to shorten overly long copyright terms and route works into the public domain. This distinct cost-benefit mix raises a puzzle: If copyright

${ }^{125}$ See infra Part IV. 
abandonment inflicts costs on owners, and primarily benefits the public, why would an owner ever abandon their work?

Despite what rational-choice theory might predict, many copyright owners - individuals and institutions alike - seek to place high-value works in the public domain. Both artists and institutions seek to give up control over their works. Photographer Carol Highsmith, for example, has donated tens of thousands of photos to the Library of Congress, expressly seeking to relinquish copyright. ${ }^{126}$ Jason Rohrer, the developer of popular video games like One Hour One Life, disclaims any copyright and considers his works part of the public domain. ${ }^{127}$ And software developers have for decades released their programs under either explicit public domain dedications or pursuant to licenses that approximate such dedication. And museums such as the Metropolitan Museum of Art have sought to dedicate tens of thousands of works to the public domain.

Demand for a simple mechanism to disclaim copyright was sufficiently high that Creative Commons developed its $\mathrm{CC} 0$ designation. Unlike typical permissive licenses which rely on copyright ownership, CC0 is meant to "place [designated works] as completely as possible in the public domain," 128 reflecting the rights holder's "wish to permanently relinquish those rights to a Work for the purpose of contributing to a commons of creative, cultural and scientific works." 129 But given the uncertainty surrounding the legal status and application of abandonment, even Creative Commons acknowledges the difficulty of dedicating a work to the public domain before the expiration of the statutory copyright term. ${ }^{130}$ The key operative provision of the $\mathrm{CC} 0$ instrument outlines a "waiver" of copyright:

\footnotetext{
${ }^{126}$ Carey Dunn, Photographer Files \$1 Billion Suit Against Getty for Licensing her Public Domain Images (July 27, 2016), https://hyperallergic.com/314079/photographer-files-1-billion-suit-against-gettyfor-licensing-her-public-domain-images/.

127 See jasonrohrer, Comment to Open Letter to the Mobile Developers, $\begin{array}{llllll}\text { Onehouronelife.com forums } & \text { (Mar. } 1, & 2019 & 5: 48 & \text { AM), }\end{array}$ http://onehouronelife.com/forums/viewtopic.php?id=5479.

128 CCO, CREATIVE COMMONS, https://creativecommons.org/share-yourwork/public-domain/cc0.

129 CCO $1.0 \quad$ Universal, CREATIVE COMMONS, https://creativecommons.org/publicdomain/zero/1.0/legalcode.

${ }^{130}$ The shift from earlier Creative Commons Public Domain Dedication to CC0 reflects, in part, these challenges. See Armstrong, supra note 6, at 423.
} 
To the greatest extent permitted by, but not in contravention of, applicable law, Affirmer hereby overtly, fully, permanently, irrevocably and unconditionally waives, abandons, and surrenders all of Affirmer's Copyright and Related Rights... fully intending that such Waiver shall not be subject to revocation, rescission, cancellation, termination, or any other legal or equitable action. ${ }^{131}$

In addition, the $\mathrm{CC} 0$ terms contain a "fallback" license. In the event the waiver is deemed legally invalid, the terms provide for "a royalty-free, non-transferable, non-sublicensable, non-exclusive, irrevocable and unconditional license to exercise Affirmer's Copyright and Related Rights in the Work."132 In part, this belt-and-suspenders tactic is demanded by the global reach of Creative Commons. CC0 is meant to apply across jurisdictions with very different approaches copyright abandonment. But as we will demonstrate in Part III, it reflects the confused and unsettled law of abandonment in U.S. copyright law in particular.

Despite the uncertainty as to its precise legal effect, CCO has been widely adopted. Nina Paley's critically acclaimed film Sita Sings the Blues is distributed under the $\mathrm{CC} 0$ instrument. ${ }^{133}$ The same is true for nearly 4 million photos, including nearly 400,000 images from the Metropolitan Museum of Art, ${ }^{134}$ 100,000 from the Paris Musées, ${ }^{135}$

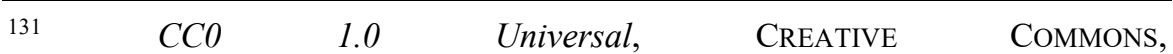
https://creativecommons.org/publicdomain/zero/1.0/legalcode.

${ }^{132} I d$.

${ }^{133}$ Nina Paley, Ahimsa: Sita Sings the Blues now CC-0 “Public Domain," (Jan. 13, 2018), https://blog.ninapaley.com/2013/01/18/ahimsa-sita-sings-the-blues-now-cc0 -public-domain/

${ }^{134}$ Jennie Rose Halperin, New York's Metropolitan Museum of Art releases 375,000 digital works for remix and reuse online via CCO, CREATIVE COMMONS (Feb. 7, 2017), https://creativecommons.org/2017/02/07/met-announcement/.

${ }^{135}$ Victoria Heath, Paris Musées Releases 100,000+ Works Into the Public Domain, Creative Commons (Jan. 2020), https://creativecommons.org/2020/01/10/paris-musees-releases-100000-worksinto-the-public-domain/.
} 
and 30,000 from the Cleveland Museum of Art. ${ }^{136}$ And websites like Freesound offer hundreds of thousands of CC0 sound recordings. ${ }^{137}$

Prior to the emergence of the contemporary free software movement, which relies on copyright to both grant permission and often to impose restrictions on the use of licensed works, many early software developers contributed their works to the public domain. ${ }^{138}$ Such works were often distributed without copyright notices, and assumed to be free of any exclusive rights. But in the post-Berne era of automatic copyright protection, more proactive strategies emerged. While various popular free software licenses continue to leverage copyright protection, in 2010 developer Arto Bendiken released the Unlicense, an instrument designed to "dedicate any and all copyright interest in the software to the public domain ... in perpetuity of all present and future rights." ${ }^{139}$ More than 100,000 projects on GitHub are made available under the terms of the Unlicense. ${ }^{140}$

These examples reveal that the motivations for abandonment go beyond purely economic calculations. That's not to say placing a work in the public domain couldn't redound to the author's financial benefit. A work that is widely available at no cost may increase an author's visibility, spark interest in other work, or lead to opportunities for live performance or other paid services. ${ }^{141}$ Jason Rohrer, for example, still makes money from the games he makes and dedicates to the public domain by charging for access to the servers on which they are played. ${ }^{142}$

\footnotetext{
${ }^{136}$ Jennie Rose Halperin, $C C 0$ at the Cleveland Museum of Art: 30,000 high quality digital images now available, CREATIVE COMMONS (Jan. 23, 2019), https://creativecommons.org/2019/01/23/cleveland-museum.

137 See License: Creative Commons 0, FreESOUND, https://freesound.org/search/?g=1\&q=\&f=\%20license:\%22Creative + Commons +0 $\% 22$.

${ }^{138}$ Tom Shea, Free software - Free software is a junkyard of software spare parts, INFOWORLD, June 23, 1983.

${ }^{139}$ Unlicense Yourself: Set Your Code Free, https://unlicense.org.

${ }^{140}$ Ben Balter, Open source license usage on GitHub.com, GitHub Blog (March 9, 2015), https://github.blog/2015-03-09-open-source-license-usage-on-github-com.

${ }^{141}$ This is a classic "loss leader" where someone gives away something in the shortterm in the hope of making larger profits at a later time by stimulating demand and/or creating consumer goodwill.

142 See jasonrohrer, Comment to Open Letter to the Mobile Developers, Onehouronelife.com forums (Mar. 1, $2019 \quad$ 5:48 AM), http://onehouronelife.com/forums/viewtopic.php?id=5479 ("Piracy simply isn't an issue for server-based games.”). Although Rohrer stands by his decision to dedicate
} 
Alternatively, placing a work in the public domain may bring owners subjective satisfaction. Much empirical evidence has shown that giving property away can bring greater subjective well-being than hanging onto it for profit. ${ }^{143}$ Carol Highsmith's donation of works to the Library of Congress, which the Library itself called "one of the greatest acts of generosity" in its history, falls into this category. ${ }^{144}$ Abandonment may also contribute to an author's reputation or sense of belonging within her community. Before the development of the contemporary free software movement, for example, a community of programmers sought to cede their code to the public domain. ${ }^{145}$ Beyond community norms, abandonment allows owners to express and further their ideology, dedicating works to the public domain as a political or cultural gesture. ${ }^{146}$

The mismatch between rational-choice predictions and the reality of abandonment provides another illustration of the variety of motivations that shapes the relationship between creators and their works. Non-pecuniary interests spur not only the creation of new works, ${ }^{147}$ but copyright enforcement as well. ${ }^{148}$ Abandonment is no different. Rational choice alone cannot capture the variety of reasons

his games to the public domain, he has expressed frustration over adaptations of those games that fail to provide him with attribution or falsely suggest his involvement. $I d$.

143 Dave Fagundes, Why Less Property Is More, IowA L. REV. (2018) (collecting studies showing that other-oriented uses of property, such as giving to charities, tends to increase subjective well-being more than self-oriented uses).

144 Carey Dunn, Photographer Files \$1 Billion Suit Against Getty for Licensing her Public Domain Images, HyperAllergic, July 27, 2016, https:/hyperallergic.com/314079/photographer-files-1-billion-suit-against-gettyfor-licensing-her-public-domain-images/.

145 See Unlicense supra note 139.

${ }^{146}$ Cf. Rachelle Hampton, Broadly's New “Gender Spectrum” Photo Library Will Change How the World Sees Trans People, Slate.com, March 26, 2019 (describing an open-access stock photo archive designed to make it easier for users to include images of gender non-binary people in their depictions of everyday life).

147 This is true for both professionals and hobbyists. See JESSICA SILBEY, ThE EUREKA MYTH: CREATORS, INNOVATORS, AND EVERYDAY INTELLECTUAL PROPERTY (2014) (interviewing creators to reveal a variety of motivations far beyond economic self-interest); Rebecca Tushnet, Legal Fictions: Copyright, Fan Fiction, and a New Common Law, 17 LOY. L.A. ENT. L.J. 651 (1997) (outlining the culture of fan fiction and its relationship to law).

148 Buccafusco \& Fagundes, supra note 63 (showing that infringement lawsuits are often motivated by moral considerations rather than purely economic ones); John Tehranian, The New Censorship, 101 IowA L. REV. 245 (2018) (cataloguing numerous copyright infringement lawsuits designed only to suppress expression the owner dislikes). 
that that owners abandon their works. This point will be crucial when we turn to optimizing abandonment in Part IV.

The social costs of abandoning copyrights are the opposite of those accompanying physical property abandonment. While abandoning chattels tends to benefit owners and to externalize costs to society, abandoning copyrights appears to be costly only to owners while conferring significant benefits to society. Despite this inverse cost-benefit equation, abandonment — or at least attempts at it —occurs with surprising frequency. As the next Part reveals, however, the law of abandonment frustrates both rights holder and potential users of their works.

\section{THE LAW OF COPYRIGHT ABANDONMENT}

As Part II revealed, a surprising number of copyright holders seek to abandon their works, even works of nontrivial value. But even for copyright holders who prefer abandonment, the legal mechanisms by which a work can be fully abandoned remain far from clear. The Copyright Act contains no abandonment provision; the Copyright Office, while accepting notices of abandonment, declines to weigh in on their legal effect; and although the courts generally agree on the basic doctrinal framework for abandonment, their application of that test has been inconsistent and unpredictable. Not only does a copyright holder committed to abandoning her work lack a clear, reliable mechanism for parting with her creation, but the copyright system lacks any broadly accessible record of abandoned works, further undermining the practical effectiveness of abandonment. In this Part, we outline the statutory, administrative, and judicial treatment of abandonment. We focus particular attention on the ways in which courts have struggled to articulate and consistently apply a clear abandonment standard.

\section{A. Statutory Silence}

The Copyright Act of 1976 says nothing about abandonment. ${ }^{149}$ Neither do the Acts of 1909 or $1790 .{ }^{150}$ The failure to explicitly address abandonment is perhaps understandable under the pre-1976

\footnotetext{
149 The terms "abandon" and "abandonment" do not appear in Title 17 of the United States Code.

15035 Stat. 1075 et seq. (1909); 1 Stat. 124 et seq. (1790).
} 
regimes, given their opt-in structure. Under those earlier Acts, owners who did not want a copyright could simply decline to engage in the formalities necessary for federal protection. But under the 1976 Act, copyrights vests automatically. The resulting proliferation of copyrights makes the lack of any abandonment mechanism a more consequential absence.

Prior to the 1976 Act, federal statutory copyright protected works only if they were published with proper notice. If an author published a work within the meaning of the statute without adequate notice, they forfeited federal copyright and the work entered the public domain. ${ }^{151}$ Although Congress may not have designed these forfeiture rules with abandonment in mind, an author determined to abandon their work could easily leverage copyright's formal requirements to do so. ${ }^{152}$ They simply needed to publish the work without notice, and it would be free for all to use. In effect, copyright formalities created a statutory back door for abandonment.

But as of January 1, 1978 - the effective date of the 1976 Actfederal law protects all copyrightable works from the instant of their creation, regardless of whether or not they are published. Any work of authorship sufficient to satisfy the low bar of originality is imbued with copyright protection from the moment it is fixed in a tangible

${ }^{151}$ See Twin Books Corp. v. Walt Disney Co., 83 F.3d 1162, 1165 (9th Cir. 1996) ("If the owner failed to satisfy the Act's requirements, the published work was interjected irrevocably into the public domain precluding any subsequent protection of the work under the 1909 Copyright Act."). In response to the harsh consequences of publication without proper notice, courts developed the distinction between general and limited publication. The latter did not result in forfeiture. See White v. Kimmell, 193 F.2d 744, 746-47 (9th Cir. 1952) ("a limited publication which communicates the contents of a manuscript to a definitely selected group and for a limited purpose, and without the right of diffusion, reproduction, distribution or sale... does not result in loss of the author's common-law right to his manuscript"). ${ }^{152}$ The legislative history of the 1976 Act reveals some congressional awareness of the use of copyright formalities to intentionally relinquish rights. To the extent Congress recognized this practice, it sought to address it by reducing or eliminating opportunities for losing copyright, intentional or not. See H.R. REP. 94-1476, 151, 1976 U.S.C.C.A.N. 5659, 5767 (noting that the deposit requirement "resulted in many artists choosing to forfeit copyright protection rather than bear the expense of depositing 'two copies of the best edition.'); see also id. at 147 ("omission of notice, whether intentional or unintentional, does not invalidate the copyright if either of two conditions is met..." 
medium ${ }^{153}$ Initially, an owner could still lose a vested copyright upon publication without proper notice under the 1976 Act, although this omission could be cured. ${ }^{154}$ But since the United States enacted legislation in 1989 to comply with the Berne Convention, notice is no longer required to either secure or maintain copyright protection. ${ }^{155}$

Such a system is bound to give rise to a massive number of unintentional, if not affirmatively unwanted, copyrights. One might reasonably expect then that this shift from an opt-in copyright regime - one that required some affirmative steps to secure federal protection - to an automatic system - one that protects all eligible works by default - would provide some mechanism for opting out of copyright's entitlements. But the 1976 Act is silent on whether or how a copyright holder may dedicate their work to the public domain or otherwise abandon their ownership interest in a work. ${ }^{156}$ Whatever the standards or procedures are for abandoning copyrights, they are not found in the Act itself.

\section{B. Administrative Agnosticism}

The U.S. Copyright Office, housed within the Library of Congress, is the administrative body charged with, among other duties, registering copyrights and recording transfers and other transactions relating to copyrighted works. Stretching back to the late nineteenth century, the Copyright Department, as it was then known, has played an important role in administering the various aspects of the copyright system. As copyright law has grown increasingly complex, the rules, practices, and responsibilities of the Office have expanded apace. ${ }^{157}$ The Office has not only defined rules relating to the formal and substantive requirements for registration, compliant notice, and sufficient deposit of copies, but it has overseen and collected statutory licenses, and weighed in on a range of questions of copyright policy as well.

Beginning in 1973, the Office began to collect and publish its

15317 U.S.C. $\S 102$ (2018) (Copyright protection subsists, in accordance with this title, in original works of authorship fixed in any tangible medium of expression).

${ }^{154} I d . \S 405(\mathrm{a})$

${ }^{155} \mathrm{Id}$.

${ }^{156} I d . \S \S 204 \& 205$ (2018).

${ }^{157}$ See Aaron Perzanowski, The Limits of Copyright Office Expertise, 33 BERKELEY TECH. L.J. 733 (2018). 
various policies and procedures in the Compendium of U.S. Copyright Office Practices. The most recent edition, consistent with the two prior major revisions, addresses abandonment. The Compendium provides that copyright holders may "record an affidavit, declaration, statement, or any other document purporting to abandon a claim to copyright or any of the exclusive rights." 158 Such a document "should identify ... the author(s), title(s), and registration number(s) for the works (if any)." 159 And it "should state that the rights specified in the document have been abandoned." 160 Notices of abandonment are subject to the same recordation fees that apply to assignments or other transfers of ownership, currently $\$ 105$ for a single work. ${ }^{161}$ Crucially, however, the Copyright Office takes no position on whether a duly recorded document that meets these criteria and "purports" to abandon a work is effective. ${ }^{162}$ "The Office will record an abandonment ... without offering any opinion as to the legal effect of the document."163

${ }^{158}$ U.S. Copyright Office, Compendium of U.S. COPyright Office Practices $\S 2311$ (3d ed. 2017). See also U.S. Copyright OfFice, CoMpendium OF U.S. COPYRIGHT OFFICE PRACTICES $\S 12.4 .2$ (1973) ("Although there is no provision in the copyright law for abandoning a copyright, the Copyright Office will record an affidavit or signed statement of abandonment without offering any opinion as to its legal effect."); U.S. COPYRIGHT OfFICE, COMPENDIUM OF U.S. COPYRIGHT OFFICE PRACTICES $\S 1507.14$ (2d ed. 1984) ("There is no provision in the copyright statute for abandoning a copyright or copyright claim or any of the rights therein. However, the Copyright Office will record an affidavit or other statement, signed by all of the copyright owners, purporting to abandon the copyright, without expressing any opinion concerning its legal effect.").

${ }^{159} I d$. The Compendium (Second) required "clear words of present abandonment." Id. § 12.4.2.

160 COMPENDIUM (THIRD) $\S 2311$.

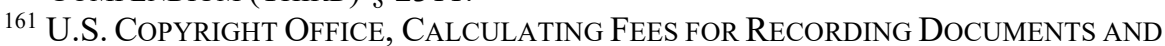
Notices OF TERMINATION IN THE COPYRIGHT OfFice (2014), https://www.copyright.gov/fls/s104d.pdf. In contrast, copyright protection under the 1976 Act is automatic and free, and optional registration costs as little as $\$ 35$ for a single work.

162 Section 805 of Computer Software Rental Amendments Act of 1990 refers to "public domain computer software" and provides for the donation of copies for the Machine Readable Collections Reading Room of the Library of Congress. Pub. L. No. 101-650, 101st Cong., 2d Sess., 104 Stat. 5089. According to the Copyright Office "[p]ublic domain computer software means software which has been publicly distributed with an explicit disclaimer of copyright protection by the copyright owner." 37 C.F.R. § 201.26(b)(3). This suggests that, at least for software, federal law recognizes abandonment. See StePhen Fishman, Copyright AND the Public DOMAIN $§ 6.02$.

${ }^{163}$ Compendium (THIRd) $\S 2311$. 
Once received, the Office creates an online public record of the notice. ${ }^{164}$ But it does not make the content of the notice of abandonment available online. Nor does it cross-reference the record with the corresponding copyright registration or maintain a database of abandoned works. ${ }^{165}$

Our search of Copyright Office records uncovered 190 notices of abandonment filed between 1978 and 2018. On average, fewer than five notices were recorded per year over that four-decade period. In contrast, the Copyright Office recorded more than 21,000 assignments, licenses, and other transactions in 2018 alone, only three of which were notices of abandonment. ${ }^{166}$ For reasons explored below, we note an overall downward trend in works subject to notices of abandonment. They peaked in 1980 with 598 works, dwindling to just a trickle today. ${ }^{167}$

We obtained copies of 187 of the 190 abandonment notices. ${ }^{168}$ Those documents reveal considerable variation in the rationales offered by abandoning owners. The Office does not require copyright owners to provide any reasons for abandoning their works, so the vast majority are silent on this front. But several of the notices volunteer information that reveals owners' reasoning. Some abandon copyrights in what appear to be good-faith efforts to acknowledge the invalidity of their copyrights. One owner filed a notice after discovering a preexisting work, ${ }^{169}$ while another did so upon determining that their work was ineligible for protection. ${ }^{170}$ Others seek to correct clerical errors. ${ }^{171}$ Still others abandon to settle copyright disputes ${ }^{172}$ or to comply with court orders. ${ }^{173}$ For example, in an antitrust case brought

\footnotetext{
${ }^{164} \mathrm{Id}$.

165 Since the online record includes the name and registration number of only the first work listed in a notice, those records do not fully capture even those works subject to a notice filed with the Office. $I d$.

166 United States Copyright Office Annual Report For Fiscal 2018 at 7, https:/www.copyright.gov/reports/annual/2018/ar2018.pdf.

167 There were three such works in 2018; eight in 2017; and none in 2016.

168 Because these notices are not available online, this required a visit to the Copyright Office archives in Washington, D.C.

1691998 COPYRIGHT RECORD. 781 (1984).

1701955 COPYRIGHT RECORD. 162 (1982).

171 See, e.g., 1733 COPYRIGHT RECORD. 154 (1979); 1737 COPYRIGHT RECORD. 26 (1979).

1721883 COPYRIGHT RECORD. 128 (1981); 1909 COPYRIGHT RECORD. 333 (1982).

1732953 COPYRIGHT RECORD. 563 (1993); 2236 COPYRIGHT RECORD. 436 (1986).
} 
by a cake decoration supplier against two larger competitors, the court ordered the defendants to "prepare, execute and file with the Register of Copyrights notices of abandonment of all claims to copyright in [various decorations and related materials]."174

By contrast, some copyright holders abandon their works out of a sense of altruism or a desire to reach a broader audience. When Bruce MacNaul abandoned his copyrights on various legal publications, he noted his "intention that any person be able to utilize these works and the information contained therein."175 And when Robert Lynott abandoned the copyright in his book on weather forecasting, he expressed his "desire to remove the obstacle of copyright [because] [d]issemination is more important than money."176

Other copyright holders were motivated by economic considerations, in particular avoiding the manufacturing clause. ${ }^{177}$ Under now-repealed section 601 of the 1976 Act, it was unlawful to import or distribute copies of English language literary works unless those copies were manufactured in the United States or Canada. ${ }^{178}$ The manufacturing clause was nakedly protectionist, designed to insulate domestic printers and publishers from low-cost international competition. However, since it applied only to works protected by U.S. copyright, the clause could be circumvented by abandoning rights in a work.

So where concern over unauthorized duplication was low, some companies chose to forego copyright protection and print copies of their works overseas. Under the regulations of the day, an unlimited number of copies manufactured abroad could be imported on a showing "that a statement of abandonment of copyright has been filed and recorded in the copyright office and the notice of copyright is completely obliterated from the works sought to be imported." ${ }^{179}$ For example, a company that prints hundreds of thousands of computer

\footnotetext{
${ }^{174}$ Parrish's Cake Decorating Supplies V. Wilton Enterprises, No. 75 C 4400, 1984 WL 2942 (N.D. Ill. Feb. 16, 1984); see also 2068 COPYRIGHT RECORD. 49 (1984).

1751955 COPYRIGHT RECORD. 162 (1982).

1762798 COPYRIGHT RECORD. 334 (1992).

1772024 COPYRIGHT RECORD. 251 (1983) (explaining that copyright in religious pamphlets was being abandoned to permit importation of material printed internationally).

17817 U.S.C. § 601(a) (1985).

179 Authors League of Am. v. Oman, 790 F.2d 220, 221 (2d Cir. 1986) (citing 19 C.F.R. § 133.51(b)(3) (1985)).
} 
manuals might be willing to part with their copyrights if international printing offers significant cost savings. ${ }^{180}$

In terms of the number of works abandoned, the four-decade average is about 34 works per year. ${ }^{181}$ From 1978 though 1986, the final year of the manufacturing clause, owners filed to abandon an average of 110 works per year. From 1987 until 2018, that average dropped to just over 12 works per year. ${ }^{182}$ This suggests that the ability to manufacture and print copies internationally drove some abandonment decisions.

Finally, copyright holders employ a variety of language to convey abandonment in the filed notices. Many simply state that they "hereby abandon" a particular work. Others expressed their intent to "abandon, surrender and disclaim all right, title, and interest in and to [the work]" 183 or "irrevocably surrender, relinquish, abandon, dedicate to the public and inject into the public domain any and all copyrights;"'184 or "irrevocably [] relinquish and abandon [their] Registrations and the claims described therein" 185 Each of these phrasings seem to establish unambiguously the copyright holder's intent to abandon their work. But as the next section demonstrates, courts have struggled to define and apply a precise standard for abandonment.

180 Hewlett Packard, for example, abandoned its copyrights in 246 works in 1984 including various owner's manuals and instructional materials. 2095 COPYRIGHT RECORD. 158 (1985); id. at 163.

${ }^{181}$ Although many of the notices identify a single work to be abandoned, others list dozens or even hundreds of such works. Id., 1824 COPYRIGHT RECORD. 186 (1980). ${ }^{182}$ A similar trend is visible by examining the number of notices filed. Over 40 years, owners filed an average of 4.6 notices each year. In the manufacturing clause era, that average was nearly 7 notices per year. In the years that followed, the average dropped to fewer than 4 notices annually. Two outlier years in which the same copyright holder filed separate notices for multiple works drove the number higher. 1833031 COPYRIGHT RECORD. 102 (1984).

1843426 COPYRIGHT RECORD. 811 (1999).

1853620 COPYRIGHT RECORD. 415 (2012). One distinction that emerges from the notices is that between the intent to abandon a work and the intent to abandon a registration. Often the work and registration are referred to interchangeably, or they are abandoned in tandem. But in some instances, copyright holders claim to abandon a registration while reserving rights in the underlying work. See, e.g., 2784 COPYRIGHT RECORD. 462 (1992) (insisting that abandonment of registration "in no way constitutes an abandonment of the work"); 3422 COPYRIGHT RECORD. 930 (1999); 3596 Copyright ReCORD. 345 (2010); 9952 Copyright ReCORD. 366 (2018). 


\section{Judicial Uncertainty}

Given the absence of any explicit or reliable statutory or administrative mechanism for abandoning copyrights, courts facing claims of copyright abandonment have borrowed from the law of personal property. In both contexts, abandonment is the intentional relinquishment of a legal interest as manifested by some overt act. But the abandonment of rights in intangible works is, at best, an imperfect analog to the abandonment of physical assets.

To more fully understand how courts conceptualize, interpret, and apply the doctrine of abandonment in the copyright context, we have identified and analyzed what we believe are every state and federal opinion containing a substantive analysis of what courts term copyright "abandonment." In all, that dataset includes 293 decisions. ${ }^{186}$ The earliest dates from 1834, and the most recent were decided in 2019. Of these 293 decisions, however, 131 exclusively address questions of copyright forfeiture, rather than abandonment proper. Of the remaining 162 decisions that squarely address abandonment, only 17 found that the works in question had, in fact, been abandoned. In addition, we identified a handful of decisions that, while not containing the term "abandonment," nonetheless offer analyses that track the doctrine that emerges from the cases.

Our examination of these decisions suggests that, not unlike their chattel property counterparts, the copyright abandonment cases reveal considerable confusion, uncertainty, and inconsistency. First, courts have failed to reliably distinguish between abandonment and a number of related, but conceptually and practically distinct doctrines. In part, this confusion reflects the extent to which abandonment was doctrinally intertwined with the formalities that prevailed in copyright law prior to the 1976 Act. Since then, courts have delineated some of these doctrines more clearly. But others remain muddled. Second, aside from the bare recitation of the common law test for abandonment, a fully-realized and consistently-applied doctrine has yet to take shape. Given the paucity of cases where abandonment defenses prevail, it remains difficult to predict with much confidence which acts courts will deem sufficient evidence of the subjective intent

\footnotetext{
${ }^{186}$ We identified these by searching Westlaw for "copyright $/ 5$ abandon!" That search yielded 437 cases. We then manually reviewed the results and removed more than 100 false positives. Those included decisions that made passing references to "abandonment" and those that involved abandonment of non-copyright interests.
} 
to abandon.

Both the doctrinal conflation and the absence of guidance as to divining intent obscure the path to effective abandonment. That fact frustrates rights holders contemplating abandonment, introduces uncertainty for users of plausibly abandoned works, and leaves courts poorly equipped to resolve disputes between them.

\section{Distinguishing Adjacent Doctrines}

Before we examine how courts have resolved genuine cases of alleged abandonment, it is necessary to distinguish abandonment from a cluster of related doctrines. This clarification is important because courts are often imprecise in their terminology. And that imprecision obfuscates the contours of abandonment. For instance, courts frequently refer to "abandonment" when cases actually present a question of forfeiture. At other times, courts blur the line between abandonment and a number of related, but distinct doctrines including acquiescence, waiver, estoppel, and implied license. So before explaining what abandonment is, we begin by explaining what it isn't.

Copyright abandonment - the intentional relinquishing of rights in a work as manifested through some overt act-is closely related to forfeiture - the unintentional loss of copyright due to a failure to comply with some formal requirement. Most commonly, forfeiture occurred when a would-be copyright holder engaged in a general publication without proper notice of copyright.

Abandonment and forfeiture are different in crucial respects, however. Abandonment requires the owner's intention to give up their exclusive rights in the work, while forfeiture divests the copyright holder by operation of law irrespective of their intent. But courts frequently use these terms interchangeably, referring to "abandonment" when the case actually involves forfeiture. ${ }^{187}$ This mistake is understandable given that under the pre-1976 regime works could be abandoned by publication without notice - the very same act that constituted the bulk of forfeiture cases. But the two doctrines are not equivalent. An author who tries but fails to provide proper notice may forfeit their copyright, but the absence of such notice alone does

${ }^{187}$ See, e.g., Koppel v. Downing, 11 App. D.C. 93, 1897 WL 17708 (D.C. Cir. 1897); Bentley v. Tibbals, 223 F. 247 (2d Cir. 1915); Atl. Monthly Co. v. Post Pub. Co., 27 F.2d 556 (D. Mass. 1928). 
not establish an intent to abandon. ${ }^{188}$ Conversely, an author who makes a limited, as opposed to general, publication does not automatically forfeit copyright, but they may have abandoned it if intent can be established. ${ }^{189}$

Related to the conflation of abandonment and forfeiture is the tendency to treat both as synonymous with dedication to the public domain. ${ }^{190}$ Public domain status is best understood as the legal consequence of both abandonment and forfeiture. While the term "dedication" implies some degree of intent, courts often refer to forfeiture as a public domain dedication. ${ }^{191}$ In any case, dedication is not a distinct doctrine with its own legal standard. Notably, copyrights in certain foreign works that were in the public domain were restored by the Uruguay Rounds Agreement Act in 1996 if they were forfeited, but not if they were abandoned. ${ }^{192}$

Courts also confuse abandonment and waiver. ${ }^{193}$ The two doctrines share some similarities. Both are concerned with a rights holder's intent, evidenced by some overt act, to cede some measure of control over a work. ${ }^{194}$ But while abandonment works a full

${ }^{188}$ Nat'l Comics Publ'ns v. Fawcett Publ'ns, Inc., 191 F.2d 594, 597-598 (2d Cir. 1951).

${ }^{189}$ Bell v. Combined Registry Co., 397 F. Supp. 1241,1248 (N.D. Ill. 1975) ("limited distribution, even if not widespread enough to effect a forfeiture, can, coupled with the requisite intent, cause an abandonment.").

${ }^{190}$ Fantastic Fakes, Inc. v. Pickwick Int'l, Inc., 661 F.2d 479 (5th Cir. 1981) (equating abandonment of dedication); Filmvideo Releasing Corp. v. Hastings, 426 F. Supp. 690 (S.D.N.Y. 1976) (equating failure to renew with abandonment and dedication); Blunt v. Patten, 2 Paine 393 (C.C.S.D.N.Y. 1828).

${ }^{191}$ See, e.g., Boucicault v Fox, 5 Blatchf. 87 (1862); Holmes v Hurst, 76 F. 757 (E.D.N.Y. 1896); RCA Mfg Co v Whiteman, 28 F.Supp. 787 (S.D.N.Y. 1939); Public Affairs Associates Inc v Rickover, 177 F.Supp. 601 (D.D.C. 1959); Bartok v Boosey And Hawkes Inc., 523 F.2d 941 (2d Cir. 1975).

19217 U.S.C. § 104A (2018); See Dam Things from Den. v. Russ Berrie \& Co., 290 F.3d 548, 560 (3d Cir. 2002).

${ }^{193}$ Bubble Pony, Inc. v. Facepunch Studios Ltd., No. CV 15-601(DSD/FLN), 2017 WL 1379326 (D. Minn 2017); A\&M Records v. Napster, Inc., 239 F.3d 1004 (9th Cir. 2001); Bell Atl. Bus. Sys. Servs., Inc. v. Hitachi Data Sys. Corp., No. C 9320079 JW, 1995 WL 836331 (N.D. Cal. Dec. 14, 1995). But see Capitol Records, Inc. v. Naxos of Am., Inc., 372 F.3d 471 (2d Cir. 2004) (distinct analyses of waiver and abandonment).

${ }^{194}$ Bell v. Moawad Grp., LLC, 326 F. Supp. 3d 918, 929 (D. Ariz. 2018); but see Veeck v. S. Bldg. Code Cong. Int'l, Inc., 241 F.3d 398, 409 (5th Cir. 2001) ("Copyright also may be waived as the result of a particular act, even if waiver was not the intended result"). Notably the case cited in Veeck for this proposition, Norma 
relinquishment of copyright against all users of the work, waiver is more narrowly tailored; it limits the copyright holder's rights only as to the particular party to whom the intent was communicated. ${ }^{195}$ Moreover, while waiver can be partial, applying only to some rights enjoyed by the copyright holder, most authority agrees abandonment implicates all of the copyright holder's rights. ${ }^{196}$

Estoppel and acquiescence compound the problem. As the Supreme Court recently clarified, estoppel applies "when a copyright owner engages in intentionally misleading representations concerning his abstention from suit, and the alleged infringer detrimentally relies on the copyright owner's deception."197 Acquiescence-best understood as a type of estoppel-turns on express or implied assurances made by the copyright holder to the defendant that it will not assert its copyright. ${ }^{198}$ This focus on reliance distinguishes estoppel and acquiescence from abandonment. And like waiver, even if estoppel or acquiescence can be established, the copyright holder retains ownership and the ability to enforce its copyright against the rest of the world. Nonetheless, courts have sometimes failed to clearly delineate these doctrines. ${ }^{199}$

Finally, courts have even confused abandonment with implied

Ribbon \& Trimming, Inc. v. Little, concerned the question of forfeiture. 51 F.3d 45, 48 (5th Cir. 1995) ("by failing to adhere to the statutory formalities-i.e., the copyright notice requirement - the Littles forfeited whatever copyrights they claim to have had in the ribbon flowers"), demonstrating that waiver is confused with forfeiture as well.

${ }^{195} I d$.

${ }^{196}$ See infra note 256 and accompanying text. See also WiLliam PATRY, 2 PATRY ON COPYRIGHT § 5:157 ("Waiver, properly construed, refers only to a decision not to enforce rights against a particular party and may be contrasted with abandonment, which concerns a decision to relinquish all (or arguably some) rights in the work as against the world.")

${ }^{197}$ Petrella v. Metro-Goldwyn-Mayer, Inc., 572 U.S. 663, 684-85 (2014).

${ }^{198}$ Elvis Presley Enters. v. Elvisly Yours, Inc., 936 F.2d 889, 894 (6th Cir. 1991).

${ }^{199}$ Basic Books, Inc. v. Kinko's Graphics Corp., 758 F. Supp. 1522 (S.D.N.Y. 1991) (discussing estoppel, abandonment, and acquiescence without articulating the differences between them); Bell Atl. Bus. Sys. Servs., Inc. v. Hitachi Data Sys. Corp., No. C 93-20079 JW, 1995 WL 836331 (N.D. Cal. Dec. 14, 1995) (failing to distinguish abandonment, waiver, and acquiescence); Coach, Inc. v. Kmart Corps., 756 F. Supp. 2d 421 (S.D.N.Y. 2010) (failing to distinguish abandonment and acquiescence); Am. Metro. Enters. of N. Y. v. Warner Bros. Records, Inc., 389 F.2d 903 (2d Cir. 1968) (failing to distinguish abandonment and acquiescence). 
license. ${ }^{200}$ An implied license is created when the conduct of two parties and the surrounding circumstances "demonstrate that the parties intended that the work would be used for a specific purpose."201 The right to engage in a particular use established through a contextsensitive examination of the interactions between two parties is a far cry from the sweeping loss of copyright entailed by abandonment. Moreover, implied licenses are generally revocable. Abandonment, by contrast, is forever.

As the discussion above makes clear, courts have frequently failed to accurately distinguish abandonment, its elements, and its consequences from other related doctrines. ${ }^{202}$ Having shown what abandonment is not, we now try to outline as clearly as possible what abandonment is and what evidence courts have deemed sufficient to establish it.

\section{The Unsettled Black Letter of Abandonment}

Most courts agree that copyright abandonment requires an intent to relinquish rights in a work, as manifested by some overt act by the rights holder. ${ }^{203}$ The prevailing view is that mere inaction in the

${ }^{200}$ See, e.g., Capitol Records, Inc. v. MP3tunes, LLC, 821 F. Supp. 2d 627, 647-8 (S.D.N.Y. 2011) (MP3tunes contends that by offering a promotional download from an authorized website, Plaintiffs either abandoned their copyrights altogether or authorized downloads outside of the promotional context. In either event, MP3tunes has the burden to prove the existence of such a broad implied license."); Microstar v. Formgen, Inc, 942 F. Supp. 1312, 1317-18 (S.D. Cal. 1996) (Microstar "contends it has an implied license to use the screen scenes and screen saver images in any way that it chooses. The gravamen of this argument is that by encouraging users of Duke 3D to create new levels and share them with the world, movants in effect granted an open license to use any copyrighted material, such that they have waived or abandoned any claim to copyright protection.").

${ }^{201}$ Effects Assocs. v. Cohen, 908 F.2d 555, 558-59 (9th Cir. 1990)

${ }^{202}$ See Armstrong, supra note 6, at 391-92.

${ }^{203}$ See Nat'l Comics Publ'ns, Inc. v. Fawcett Publ'ns, Inc., 191 F.2d 594, 598 (2d Cir. 1951); Capitol Records, Inc. v. Naxos of Am., Inc., 372 F.3d 471 (2d Cir. 2004); Micro Star v. Formgen Inc., 154 F.3d 1107, 1114 (9th Cir. 1998); Hampton v. Paramount Pictures Corp., 279 F.2d 100 (9th Cir. 1960). But courts still occasionally articulate other standards. See e.g. Bell v. Moawad Grp., LLC, 326 F. Supp. 3d 918, 929 (D. Ariz. 2018) ("[W]aiver or abandonment of copyright "occurs only if there is an intent by the copyright proprietor to surrender rights in his work."'); Basic Books, Inc. v. Kinko's Graphics Corp., 758 F. Supp. 1522, 1540 (S.D.N.Y. 1991) ("The plaintiff's acquiescence in the defendant's infringing acts may, if continued for a 
face of unauthorized use is insufficient, ${ }^{204}$ but some courts have suggested otherwise. ${ }^{205}$ This test mirrors the one applied in chattel property abandonment cases, from which it was borrowed. ${ }^{206}$ Despite the general consensus with respect to the appropriate test, the abandonment decisions reveal that courts struggle to draw consistent and predictable lines, leaving copyright holders uncertain about how to abandon their works and potential users guessing about their copyright status.

As we detail below, courts have confronted-and occasionally accepted - a range of overt acts as proof of the intent to abandon a copyright. Those acts tend to sort themselves into two categories. On the one hand, we have explicit notices or statements disclaiming copyright. On the other, we find a range of ambiguous behaviors that are open to diverging interpretations. The outcomes in these cases provide little guidance to future litigants. Even decisions addressing explicit verbal disclaimers - what should be the most straightforward cases - fail to yield a single, consistent standard. Cases addressing more ambiguous conduct offer even less certainty.

\section{a. Verbal Disclaimers}

A number of courts have considered whether oral or written statements that purport to disclaim copyright amount to abandonment. For the most explicit statements, courts have generally found that abandonment has occurred. But since abandonment turns on the subjective intent of the rights holder, even verbal communications are often open to competing interpretations. In some instances, we identify courts that were too eager to find abandonment. Others were reluctant to deem a work abandoned despite what we believe is clear

sufficient period of time and if manifested by overt acts, result in an abandonment of copyright.").

${ }^{204}$ Dodd, Mead \& Co. v. Lilienthal, 514 F. Supp. 105, 108 (S.D.N.Y. 1981); Hampton v. Paramount Pictures Corp., 279 F.2d 100 (9th Cir. 1960).

${ }^{205}$ Dam Things from Den. v. Russ Berrie \& Co., 290 F.3d 548 (3d Cir. 2002) ("there must be either an act, or a failure to act, from which we can readily infer an intent to abandon the right.").

${ }^{206}$ See, e.g., Griffis v. Davidson Cnty. Metro. Gov't, 164 S.W.3d 267, 272 (Tenn. 2005) ("[A] complainant... must show both intent to abandon for the stated limitations and some external act or omission by which the intent to abandon is effectuated."). 
evidence of intent.

Bates $v$ Keirsey presents an easy case of abandonment. The authors and copyright holders of the book Please Understand Me wanted to import copies from Hong Kong. In order to avoid the manufacturing clause, Bates and Keirsey signed a document entitled "Abandonment of Copyright" that read in part "We hereby abandon our copyright to the book titled Please Understand Me..." ${ }^{207}$ The court was convinced that the "evidence unequivocally establishe[d]" that Bates engaged in an overt act demonstrating his intent to abandon. ${ }^{208}$

Likewise, the court dismissed Carol Highsmith's claims when she sued Getty Images for falsifying copyright information. ${ }^{209}$ The stock photo firm charged for licenses to use photos that Highsmith made freely available through the Library of Congress. ${ }^{210}$ Claims under $\S$ 1202 require an "intent to induce, enable, facilitate, or conceal infringement." 211 But as part of her gift to the Library, Highsmith "dedicate[d] to the public all rights, including copyrights, throughout the world ... in this collection." 212 As a result, the works were in the public domain, and infringement was impossible.

In Hadady Corp. v. Dean Witter Reynolds, Inc., the publisher of a newsletter included the following statement in its copyright notice: "The information contained in this letter is protected by U.S. copyright laws through noon EST on the 2d day after its release...." Hadady denied that this statement expressed an intent to abandon, a contention the court concluded "fl[ew] in the face of the only possible meaning"

\footnotetext{
${ }^{207}$ Bates v. Keirsey, No. D041368, 2004 WL 2850153 (Cal. Ct. App. Dec. 13, 2004).

${ }^{208}$ We Shall Overcome Found. \& Butler Films v. Richmond Org., Inc., 330 F. Supp. 3d 960 (S.D.N.Y. 2018) (as part of settlement, copyright holders "agree[d] that hereafter they will not claim copyright in the melody or lyrics of any verse of the song 'We Shall Overcome"'); J2F Prods., Inc. v Sarrow, No. CV097000JSTFFMX, 2011 WL 13185746 (C.D. Cal. Jan. 12, 2011) (counterclaimant explicitly abandoned copyright via written notice of abandonment); Capitol Records, Inc. v. Naxos of Am., Inc., 274 F. Supp. 2d 472 (S.D.N.Y. 2003) (finding abandonment after copyright holder "confirmed that a third party 'was wrong in believing' he needed a letter of authorization ... before he could copy a recording 'when the recording in question is public domain."').

${ }^{209}$ Order, First Amended Complaint, Highsmith v. Getty Images, No. 16-cv-05924 (S.D.N.Y.).

${ }^{210}$ First Amended Complaint, Highsmith v. Getty Images, No. 16-cv-05924 (S.D.N.Y.).

211 17 U.S.C. $\$ 1202$ (2018).

${ }^{212}$ First Amended Complaint, Exhibit I, Highsmith v. Getty Images, No. 16-cv05924 (S.D.N.Y.).
} 
of the notice. ${ }^{213}$ As in Bates and Highsmith, the court found abandonment on the basis of an unambiguous statement offered freely by the copyright holder.

But not all statements offer such clear evidence of intent. For example, architect Paul Oravec entered building plans in a competition to design the new World Trade Center. ${ }^{214}$ As a condition for entering that competition, Oravec signed a letter "signifying [his] agreement that [he] reserve[d] no patent, trademark, copyright, trade secret or other intellectual property rights in any of the material that forms or is contained in [his] proposal." 215 This language is at best ambiguous. It could be read to effectuate a broad abandonment, but is more plausibly understood in context to effectuate a waiver of rights that extended only to the entity running the contest, the counterparty in the agreement. Oravec did not win the contest, but his designs were allegedly copied by the Florida developers of the Trump Palace and Trump Royale. When he sued for infringement, the court held he had abandoned his copyright interests by virtue of his agreement to the contest rules. ${ }^{216}$

Similarly, in Wyatt Technology Corp. v. Malvern Instruments Inc. the predecessor in interest of the copyright holder distributed a software program with a notice that read: "Currently, there are no restrictions on this material. You may install it on as many PC systems as you like, and you may distribute it freely to your colleagues."217 The term "currently" would seem to preclude reading the language as expressing an intent to abandon. Instead, it appears to reserve a right to alter these permissive terms at a later date. Despite a witness who testified that the developer "never intended to 'abandon"" its rights, the court determined the notice indicated an intent to abandon. ${ }^{218}$

${ }^{213}$ Hadady Corp. v. Dean Witter Reynolds, Inc., 739 F. Supp. 1392, 1399 (C.D. Cal. 1990)

${ }^{214}$ Oravec v. Sunny Isles Luxury Ventures L.C., 469 F. Supp. 2d 1148 (S.D. Fla. 2006).

${ }^{215} \mathrm{Id}$. at 1154.

${ }^{216} \mathrm{Id}$. at $1177-78$.

${ }^{217}$ Wyatt Tech. Corp. v. Malvern Instruments Inc., No. CV 07-08298DDP(MANX), 2009 WL 2365647 (C.D. Cal. July 29, 2009).

${ }^{218}$ Id. See also Rouse v. Walter \& Assocs. L.L.C., 513 F. Supp. 2d 1041 (S.D. Iowa 2007) (finding abandonment where software was created with a tool that prohibited privately owned software, where copyright notices did not mention plaintiff, but rather plaintiff's employer, plaintiff signed an agreement that referred to the program 
In other instances, however, courts have declined to find abandonment despite seemingly clear statements by rights holders. Melchizedek $v$ Holt concerned the copyright in a meditation video. ${ }^{219}$ In an open letter, the creator of the video explained that he "let the video go out to the world unrestrained. No control on the copyrighted material. No money coming back to me from the videos." ${ }^{220} \mathrm{He}$ went on to explain that he "never cared about the copyrights [and] wanted the information to go out to the world." ${ }^{221}$ Later he told workshop attendees that he "do[es]n't care about copyrights or any of that stuff, that doesn't matter." ${ }^{222}$ Nonetheless, the court found the evidence insufficient to establish abandonment.

As these cases demonstrate, even when copyright holders offer oral or written disclaimers of rights, it is often difficult to predict whether a court will find abandonment has occurred. ${ }^{223}$

\section{b. Other Overt Acts}

The overt act requirement may also be satisfied by conduct rather than language. Defendants often point to some non-verbal act of the owner that arguably expresses a desire to abandon a copyright. These purported defenses are often implausible, and sometimes border on the frivolous. ${ }^{224}$ Defendants have insisted copyrights were abandoned when: a book went out of print, ${ }^{225}$ software was designated open

as property of plaintiff's employer ISU, plaintiff claimed program was owned by employer in a published article.).

${ }^{219}$ Melchizedek v. Holt, 792 F. Supp. 2d 1042 (D. Ariz. 2011).

${ }^{220} \mathrm{Id}$. at 1048.

${ }^{221} I d$.

${ }^{222} \mathrm{Id}$.

${ }^{223}$ This lack of a clear standard may explain in part the current posture of the Furie case. The creator of Pepe the Frog made a number of statements that could only tepidly be understood to indicate abandonment, such as "I believe in supporting people's decisions to profit off Pepe." Rather than resolving the issue as a matter of law, though, the court simply punted the case to a jury, holding that the statements did not clearly indicate intent to abandon (or its absence).

${ }^{224}$ See, e.g., Corwin v. Walt Disney Co., No. 602CV1377ORL19KRS, 2004 WL 5486639 (M.D. Fla. Nov. 12, 2004); Covington Indus., Inc. v. Nichols, No. 02 CIV. 8037 (KTD), 2004 WL 784825 (S.D.N.Y. Apr. 12, 2004).

${ }^{225}$ Dodd, Mead \& Co. v. Lilienthal, 514 F. Supp. 105 (S.D.N.Y. 1981). 
source, ${ }^{226}$ images were uploaded to Wikimedia under a Creative Commons license, ${ }^{227}$ works were shared on the internet, ${ }^{228}$ and a program was broadcast on public television. ${ }^{229}$ These claims are all substantively implausible because they confuse an owner's making a work accessible to the public on a limited basis with wholesale relinquishment of control over the work. Courts are generally capable of recognizing and rejecting these grasping efforts to establish abandonment, but other conduct has resulted in less obvious determinations.

Two cases illustrate the conceptual difficulty courts sometimes face in applying a doctrine developed in the context of chattels to intangible works. When it comes to chattels, the physical disposition of the property often offers strong indications of intent. A couch placed unattended on the sidewalk is a reasonably clear sign of the owner's intent to abandon it. But under copyright law, ownership of any physical embodiment of a work is distinct from ownership of the copyright in the intangible work. ${ }^{230}$ This creates inevitable doctrinal tension as an owner's actions and intentions with respect to copies may not carry over to the work embodied in those copies.

Pushman v New York Graphic Society epitomizes this tension. The plaintiff sold the defendant an original painting and sued for infringement after it created reproductions. ${ }^{231}$ The court found that "the absolute sale and delivery of the painting without any condition, reservation or qualification of any kind, to a state-owned public institution where it has been displayed for a long period of time, constitute an abandonment of all the plaintiff's rights and a publication and dedication to public use free for enjoyment and reproduction by

${ }^{226}$ Blizzard Entm't Inc. v. Lilith Games (Shanghai) Co., No. 3:15-CV-04084-CRB, 2017 WL 2118342 (N.D. Cal. May 16, 2017).

${ }^{227}$ Philpot v. World Publ. Library Ass'n, No. CV 18-00057 DKW-RLP, 2018 WL 3422777 (D. Haw. June 25, 2018).

${ }^{228}$ Rosen v. Martin, No. CV120657ABCFMOX, 2012 WL 12845103 (C.D. Cal. June 7, 2012); Dolores Press, Inc. v. Robinson, 766 Fed. App'x 449 (9th Cir. 2019); Strike 3 Holdings, LLC v. Doe, 370 F. Supp. 3d 478 (E.D. Pa. 2019).

${ }^{229}$ Encyclopaedia Britannica Educ. Corp. v. Crooks, 542 F. Supp. 1156 (W.D.N.Y. 1982).

${ }^{230} 17$ U.S.C. $§ 202$ (2018); but see Pushman v. N.Y. Graphic Soc. 25 N.Y.S.2d 32 (Sup. Ct. 1941)

${ }^{231} I d$. 
anybody." 232 The court treated the owner's relinquishment of control over the copy - the painted canvas - as expressing relinquishment of control over the work - the abstract image embodied in the painting. This conflation of the copy with the work has been abrogated by the 1976 Copyright Act. ${ }^{233}$

Likewise, in Pacific and Southern Co. $v$ Duncan, the court interpreted the destruction of a videotape recording as a demonstration of the rights holder's intent to abandon its copyright. ${ }^{234}$ There, a television station sued a television monitoring service that recorded and sold a copy of a segment from the station's news broadcast. Although the station retained copies of pre-taped segments, it generally destroyed all copies of its news programs soon after they were broadcast. According to the court, the station's "destruction of its broadcast videotapes is certainly" an overt act that "evidences an intention to abandon [its] copyright." 235 Here, too, the court inferred from an owner's destructive act with respect to a copy that they had an intent to abandon the work embodied in that copy. Without additional evidence of intent, this inference is untenable. The station may have deleted the tape for a number of reasons. It may have lacked the space necessary to archive every broadcast, example. Certainly, nothing about its private archiving practices communicated to the defendant its intent to abandon.

In other cases, despite the generally agreed upon rule that failures to act are insufficient to show abandonment, ${ }^{236}$ some courts have made questionable inferences on the basis of rights holders' silence. One court held that an author's failure to object when a psychiatrist sent thousands of copies of a poem to his patients resulted in abandonment. ${ }^{237}$ Another found that the failure to object to publication of a song and its widespread use for decades worked an

\footnotetext{
${ }^{232}$ Id. But see Patterson v. J. S. Ogilvie Pub. Co., 119 F. 451 (C.C.S.D.N.Y. 1902) (finding no abandonment after the sale of printing plates because "they were mere pieces of metal, which became the property of the purchaser, but gave him no right to publish the copyrighted work which could be printed from them.").

${ }^{233}$ See Aaron Perzanowski and Jason Schultz, Reconciling Personal \& Intellectual Property, 90 Notre Dame L. ReV. 1211 (2015); 17 USC $\S 201$ (2018).

${ }^{234}$ Pac. \& S. Co. v. Duncan, 572 F. Supp. 1186 (N.D. Ga. 1983)..

${ }^{235} \mathrm{Id}$.

${ }^{236} C f$. Preseault v. United States - 100 F.3d 1525 (Fed. Cir. 1996).

${ }^{237}$ Bell v. Combined Registry Co., 397 F.Supp. 1241 (ND Ill 1975). In addition, the author described the poem as a gift to the world in his diary. Id.
} 
abandonment. ${ }^{238}$ And a third found abandonment at least in part on the basis of the copyright holder discontinuing publication of its magazine. ${ }^{239}$ These cases seem to disregard the overt act requirement entirely, mistaking an owner's inaction with respect to their copyright for an affirmative intention to place it into the public domain. ${ }^{240}$

And even when copyright holders do engage in some overt act that could be construed as abandoning the work, courts are prone to overstating their intent. In Seshadri v. Kasraian, the Seventh Circuit considered a claim of infringement brought by a professor against a former graduate student who published a research paper solely under his own name. ${ }^{241}$ Having concluded that the two were joint authors, the court had no need to resolve the question of abandonment. ${ }^{242}$ Nonetheless, Judge Posner asserted that "had Seshadri authorized Kasraian or the Journal of Applied Physics to publish the article under Kasraian's sole name, that would be abandonment - a statement or other act that demonstrates an intention of relinquishing any copyright interest in a work. Authorizing another to publish under his sole name would amount to a public disclaimer of authorship."243 Posner's dictum represents a different kind of conflation, confusing attribution and abandonment. The former is about credit; the latter is about relinquishing copyright. One can seek the latter while forgoing the former.

Some defendants have argued that owners who file works with public agencies have abandoned their copyrights, but courts have rightly tended to disagree. ${ }^{244}$ For example, an architect who submitted

${ }^{238}$ Egner v. E. C. Schirmer Music Co., 48 F. Supp. 187 (D. Mass. 1942). See Stuff v. E. C. Publ'ns, Inc., 342 F.2d 143 (2d Cir. 1965). Although stuff does not use the term "abandonment," the court concluded that the work was dedicated to the public domain, in part, because the copyright holder was "derelict" in preventing infringing uses.

${ }^{239}$ Pearson v. Washingtonian Pub. Co., 98 F.2d 245 (D.C. Cir. 1938), rev'd by Washingtonian Publ'g Co. v. Pearson, 306 U.S. 30 (1939) (addressing only the question of forfeiture).

${ }^{240}$ Copyright, unlike trademark and trade secret law, imposes no obligation to use a work in order to establish or maintain protection. See Hrdy and Lemley.

${ }^{241}$ Seshadri v. Kasraian, 130 F.3d 798 (7th Cir. 1997).

${ }^{242} I d$. (as joint authors, both parties were entitled to license reproduction of the article on a non-exclusive basis, subject only to an obligation to account to the other co-author for any revenue generated)

${ }^{243} I d$.

${ }^{244}$ Blunt v. Patten, 3 F. Cas. 762,763 (C.C.S.D.N.Y. 1828) ("the pretence that it became a public document from being deposited in the public office, was entirely 
plans in order to secure a building permit did not intend to abandon copyright in the design. ${ }^{245}$ One potential exception to this general rule is presented in Korzybski v Underwood and Underwood. ${ }^{246}$ There the plaintiff sued for infringement of his "model ... illustrating thought processes and formulating scientific information ... consisting of pieces of various shapes of geometric design, containing numerous holes and connected by strings attached to pegs." ${ }^{247}$ Crucially, the model embodied the invention described in Korzybski's patent for an "Educational Appliance." 248 As a result, the Second Circuit deemed the copyright invalid.

On one reading of the case, Korzybski engaged in general publication of his design when he submitted his application to the Patent Office. ${ }^{249}$ Presumably, that publication failed to comply with the formal requirements of the federal copyright protection, although the court was silent on that question. Although the court did not invoke the term "abandonment," we think the better reading focuses on Korzybski's intentional relinquishment of rights in light of the disclosure requirements of patent law. As the court explained, "when Korzybski filed his application and received his patent, he made a full disclosure of his invention and dedicated it to the public, save for the right to make, use, and vend it during the period for which the patent gave him that monopoly." 250

untenable."). One case sometimes cited as an example of abandonment is Heine v. Appleton, 11 F. Cas. 1031, 1032 (C.C.S.D.N.Y. 1857). There an artist on Commodore Perry's naval mission to Japan was a deemed a government employee whose work was in the public domain by virtue of that fact. But we think the case is better understood as one denying copyright to federal government works. See FISHMAN, supra note $162 \S 6.02$ (describing Heine as an abandonment case); but see PATRY, supra note $196 \S$ 4:57 (describing Heine as a case about government works). 245 Smith v. Paul 174 Cal. App. 2d 744 (1959); see also Smith v. Paul, 174 Cal. App. 2d 744 (1959) (depositing chart with the Navy did not commit it to the public domain).

${ }^{246}$ Korzybski v. Underwood \& Underwood, Inc., 36 F.2d 727 (2d Cir. 1929).

${ }^{247} \mathrm{Id}$.

248 U.S. Patent No. 1,539,194 (issued May 26, 1925).

24936 F.2d at 729 ("The filing of the application for the patent, including, of course, the diagrams, was a publication that entitled anyone to copy the drawings.").

${ }^{250}$ Regardless of the appropriate reading of Korzybski, we think it unlikely that courts today would deem copyrightable material abandoned purely by virtue of its inclusion in a patent application or an issued patent. The Court of Customs and Patent Appeals rejected the doctrine of election, which required applicants to choose between design patent and copyright protection. In re Yardley, 493 F.2d 1389 
These cases illustrate that it is usually difficult to reasonably draw an inference about an author's intentions with respect to the work by examining their behavior with respect to the copy in which that work is embodied. Thus, outside of circumstances in which filing, disclosing, or publishing a work is inconsistent with copyright protection as a matter of established law — as in Korzybski-we argue that courts should not treat non-verbal conduct as evidence of abandonment. As all of these cases illustrate, the disposition of copies is rarely indicative of copyright holder intent with respect to the underlying work. Moreover, since copyright law grants rights holders wide latitude to license their works, even impliedly, it is difficult to distinguish contingent permission to use a work from a relinquishment of rights. And given the permanent consequences of abandonment, courts should maintain a high bar for evidence of intent. ${ }^{251}$ Insisting on verbal expressions of abandonment is the best way to simultaneously facilitate abandonment when it is intended and to avoid it when it isn't.

\section{c. Partial Abandonment}

Courts are divided over the question of whether an owner can abandon some, but not all, of their interest in a work, adding to the uncertainty surrounding abandonment. Conceptually, this question is not unique to copyright abandonment. We could imagine, for example, an owner who abandons the right to sit on an old couch, but not the right to sleep on it, or parts with napping rights on weekends, but not weekdays. But the law is generally hostile to those sorts of servitudes on chattels even if they could be enforced as a practical matter. ${ }^{252}$ While contract law could accommodate such arrangements, the law of

(C.C.P.A. 1974). And courts have generally grown accustomed to overlapping intellectual property protections. See Christopher Buccafusco, Mark A. Lemley, \& Jonathan S. Masur, Intelligent Design, 68 DUKE L.J. 75, 128-130 (2018) (criticizing this trend).

${ }^{251}$ See Armstrong, supra note 6, at 395 ("Judicial reluctance to impose such severe consequences, absent the most unequivocal indication that such was the author's intent, may do much to explain the comparative scarcity of cases finding abandonment of copyright.").

${ }^{252}$ Molly Shaffer Van Houweling, The New Servitudes, 96 GeO. L.J. 885 (2008); Christina Mulligan, A Numerus Clausus Principle for Intellectual Property, 80 TENN. L. REV. 235 (2013). 
property generally, and abandonment in particular, are tools poorly suited for the job.

Unlike ownership of chattels, copyright interests are infinitely divisible. This distinction is a function of both their intangible nature and an explicit policy choice reflected in the Copyright Act. ${ }^{253}$ Copyright interests are routinely divided and subdivided - sometimes resulting in onionskin-thin rights. One party may hold an exclusive license to publish a book, with another party holding the rights to film adaptations, and yet another controlling French translation rights. And each of those rights can be further limited by geographical scope and duration. So long as these licenses are exclusive, the Copyright Act regards them as ownership interests in the underlying work.

Given this power to configure tailor-made alienable copyright interests, some courts have suggested that a copyright holder may partially abandon its interest. ${ }^{254}$ In dicta in Micro Star $v$ Formgen, for example, Judge Kozinski thought it possible that a video game developer could abandon the rights to create and freely distribute derivative works, while retaining the right to commercially distribute the same. ${ }^{255}$

Other authority, however, treats the question of abandonment as

25317 U.S.C. $\S 201(d)$ (2018).

${ }^{254}$ We located a single case, decided by the New Jersey Chancery Court in 1888 , that actually found a work was partially abandoned. Aronson v. Baker, 43 N.J. Eq. 365, 369-70 (1888) ("This question is an open one in this state; it never before having been presented for judicial consideration in this state.... The rule which I think should be adopted may be stated as follows: That the owner of a dramatic or musical composition may, like the owner of any other kind of property, do with his own as he pleases; he may retain it for his own use and benefit, or he may give it to the public out and out, or he may make a limited or partial dedication of it."). Aronson has been cited for this proposition once, in a dissent. See Kurlan v. Columbia Broad. Sys., 40 Cal. 2d 799, 817 (1953) (Carter, J. dissenting).

${ }^{255}$ Micro Star v. Formgen, 154 F.3d 1107, 1114 (9th Cir. 1998) ("Given that it overtly encouraged players to make and freely distribute new levels, FormGen may indeed have abandoned its exclusive right to do the same. But abandoning some rights is not the same as abandoning all rights, and FormGen never overtly abandoned its rights to profit commercially from new levels."). See also Taylor Holland LLC v. MVMT Watches Inc., No. 2:15-CV-03578-SVW-JC, 2016 WL 6892097 (C.D. Cal. Aug. 11, 2016) (quoting MicroStar, also dicta); Malibu Media LLC v. Doe, 381 F. Supp. 3d 343 (M.D. Pa. 2018) (leaving open possibility of abandonment of rights to reproduce and distribute videos uploaded to tubesites) (citing Columbia Pictures Indus., Inc. v. Aveco, Inc., 800 F.2d 59, 64 (3d Cir. 1986). But Aveco is actually a case about waiver and first sale, not abandonment) 
an all or nothing proposition, consistent with the doctrine's application to chattel property. As the Southern District of New York wrote when a publisher alleged that Paramount had partially abandoned its rights in Star Trek: "Defendants invite the Court to boldly go where no court has gone before and recognize the doctrine of limited abandonment. The Court declines the invitation... No pertinent authority has been cited for the proposition [of limited abandonment] and the Court knows of none." 256

Despite copyright's generally permissive approach to the divisibility and alienability of copyright interests, the binary approach better serves the aims of the abandonment doctrine. Abandonment provides a simple and clear set of rights to potential users. A work is either abandoned, in which case all may use it; or it is not, in which case use requires permission, absent some other applicable doctrine or defense. Partial abandonment would inevitably result in disputes over the precise scope of the rights abandoned, increasing information costs and setting potential traps for unwary users. ${ }^{257}$ Abandonment should be reserved for scenarios in which a right holder intends to relinquish the entirety of the statutory rights in a given work. ${ }^{258}$ Efforts to grant other forms of permission to the public should be construed as licenses.

As this Part has highlighted, the statements and behaviors alleged to establish an intent to abandon are manifold, and the courts' conclusions are sometimes inconsistent and counterintuitive. But one reasonably certain lesson we can draw from these cases is that where

${ }^{256}$ Paramount Pictures Corp. v. Carol Pub. Grp., 11 F. Supp. 2d 329, 337 (S.D.N.Y. 1998), aff'd sub nom. Paramount Pictures Corp. v. Carol Pub. Grp., Inc., 181 F.3d 83 (2d Cir. 1999) (quoting Metro-Goldwyn-Mayer, Inc. v. Showcase Atlanta Co-op. Prods., Inc., No. C79-1766, 1981 WL 1380, at *1 (N.D. Ga. Sept. 3, 1981) ("The Court is unpersuaded by Defendants' arguments that the law recognizes or should recognize the concept of 'limited abandonment' of a copyright.).

257 See Mulligan, supra note 252; MERRILL \& SMITH, supra note 12.

258 Abandonment of jointly-authored or otherwise co-owned works presents a potential complication. See 17 U.S.C. § 201 (2018) ("authors of a joint work are coowners of copyright in the work."). In the event one co-owner indicates her intent to abandon a work but the other does not, the non-abandoning owner should be considered the sole remaining owner. Abandonment is an exercise in destroying one's legal rights, an option each co-owner is free to exercise. But while one coowner may destroy her own legal interest, she cannot destroy the interests of other co-owners. Even if we consider abandonment as a transfer to the public, it is not one that a joint owner can make unilaterally. See Cortner v. Israel, 732 F.2d 267 (2d Cir. 1984) (noting that a joint author cannot transfer all interest in the work without the other co-owner's express authorization). 
a document expressly memorializes the copyright holder's intent to relinquish their rights, courts will acknowledge copyright abandonment. Given the irrevocable nature of abandonment and the risks it can present for copyright holders, we believe that a reasonably high threshold is appropriate. But as the next Part explains, it is crucial that rights holders who do choose to abandon their works can avail themselves of a clear, effective, low cost mechanism for abandonment. Just as importantly, in order to achieve the socially desirable level of abandonment, rights holders need to understand that abandoning their works is an option, and the law must provide incentives to optimize the rate of abandonment.

\section{OPTIMIZING ABANDONMENT}

The doctrinal opacity of copyright abandonment undermines its potential to populate the public domain and thereby further copyright's core objective of creating a rich cultural and informational commons. Instead, as the foregoing discussion has illustrated, the current state of abandonment generates three sets of problems for copyright owners.

First, copyright owners who want to relinquish their rights face significant information costs in terms of identifying a legally effective mechanism for abandonment. The Copyright Act is silent. The Copyright Office Compendium offers some guidance but disclaims any position of the efficacy of notices of abandonment. And while some owners use the $\mathrm{CC} 0$ mechanism to dedicate their works to the public domain, no court has yet endorsed it. And even Creative Commons expresses some degree of uncertainty about its effectiveness. Even an exhaustive review of the case law offers no definitive answers. A copyright holder who wants to abandon her work to the public domain will engage in an expensive and timeconsuming search, just to be left without any certainty about how to do so.

Second, some owners may be unwilling to abandon their works due either to the costs associated with the practice or an inflated assessment of the future value of their works. High-value works are unlikely to be abandoned. But even owners of relatively low value works may be disinclined to abandon if they overestimate their potential to generate future revenue or if incentives to abandon are simply insufficient to overcome the inertia of automatic protection. 
Third, many copyright holders are simply unaware that abandonment is an option. Indeed, given the automatic nature of protection, many are likely unaware that they are copyright holders in the first place. Here the problem is not merely that the information is hard to find ${ }^{259}$ but that abandonment as a practice is so obscure that rights holders don't know to consider it at all. ${ }^{260}$ In the absence that recognition, even reluctant copyright holders are not in a position to dedicate their works to the public. As a result, abandonment remains limited as a cultural practice. ${ }^{261}$ Since people tend to take their behavioral cues from the conduct of similarly situated people, copyright abandonment is likely to remain rare.

In this final Part, we consider three different types of strategies to ameliorate these problems: legal reforms designed to illuminate a pathway to abandonment; recalibrating owners' incentives to abandon; and developing informal norms that promise to make abandonment more likely.

\section{A. Illuminating a Pathway to Abandonment}

Given the common law origins of the doctrine, courts should make efforts to clarify the standard for copyright abandonment. In addition to clearly and consistently distinguishing abandonment from forfeiture, waiver, and related doctrines, courts should endorse clear written and oral statements of intent to abandon, but otherwise interpret purported evidence of intent narrowly. In particular, courts should disfavor efforts to establish abandonment of copyright on the

259 These two iterations of information costs are by no means mutually exclusive. On the contrary, if all copyright owners somehow instantly learned of the possibility of abandoning their works, those who found the practice appealing would still face the substantial search costs associated with effectively relinquishing rights in their work.

${ }^{260}$ As the poetics of Donald Rumsfeld would have it, it is an "unknown unknown" whereas uncertainty about how to achieve abandonment is a "known unknown." Donald H. Rumsfeld, U.S. Sec'y of Defense, Department of Defense News Briefing (Feb. 12 , 2002), http://www.defenselink.mil/transcripts/transcript.aspx?transcriptid=2636.

${ }^{261}$ This is not to say that the practice is unknown or never used. As Part II illustrated, a number of even high-value works are abandoned, particularly photographic works and software. Even so, the number of abandoned works in relation to the total universe of copyrighted works is vanishingly small, and the practice remains nearly unheard of in other creative subcultures, such as [literary works?]. 
basis of the physical disposition of copies. Such a rule would reduce confusion among both rights holders and potential users.

But in light of the often slow pace of common law development, Congress could kick start the process of clarifying abandonment in one of three ways. At the very least, it should amend the Copyright Act to acknowledge that rights holders are empowered to abandon their rights and dedicate their works to the public. ${ }^{262}$ More usefully, Congress could define a standard and associated mechanism for abandonment, ideally one that prioritizes verbal indications of intent. ${ }^{263}$ And as discussed below, Congress could also empower the

${ }^{262}$ In particular, we suggest the creation of a new $\S 201(\mathrm{f})$ of the Copyright Act that would entitle the owner of a copyright in a work to abandon that interest and irretrievably place the work in the public domain.

${ }^{263}$ One longstanding risk that could be exacerbated by a renewed interest in abandonment is its potential to disrupt the Copyright Act's termination of transfer provisions. See Robert A. Kreiss, Abandoning Copyrights to Try to Cut Off Termination Rights, 58 Mo. L. Rev. 85, 111 (1993) (noting the potential conflict between abandonment and termination). The Act gives authors opportunities to rescind decades-old licenses and assignments to regain control of their works. See 17 U.S.C. $\S \S 203 \& 304$ (2018). In order to discourage termination or influence negotiations, copyright holders could threaten to abandon the copyright in assigned works. For economically viable works, this seems unlikely, and we know of no cases where such strategic abuse of abandonment has occurred. But since abandonment is an irrevocable destruction of rights that places works in the public domain, this risk - however remote - should be addressed. One approach would forbid an assignee from abandoning rights to a work within the statutory termination notice windows. This reform would force assignees to give up some guaranteed period of exclusivity and assume the risk that no termination is forthcoming, rather than merely retaliating once a termination notice is filed.

Another approach would recognize the termination right as a future interest and subject the abandoning owner to liability for waste. See Mills Music, Inc. v. Snyder, 469 U.S. 153, 162 (1985) (labeling the post-termination interest a "reversion"); Baldwin v. EMI Feist Catalog, Inc., 805 F.3d 18, 26 (2d Cir. 2015) (calling post-termination rights a "future interest."). But that future interest does not vest, under current law, until the author serves the assignee with a termination notice. $I d$. State real property law is inconsistent on the question of whether holders of a contingent future interest can recover for waste. Compare Fed. Deposit Ins. Corp. v. Mars, 821 P.2d 826, 831 (Colo. App. 1991) ("the existence of a vested interest in the property, such as a remainder or a reversion, is a vital prerequisite to maintenance of an action for waste) and Pedro v. Jan., 261 Or. 582, 596, 494 P.2d 868, 875 (1972) (noting that "injunctive relief ... has been commonly granted to contingent remaindermen, but an assessment of damages... has been infrequent"). Once an author serves a notice, it seems, she would be able to seek an injunction to prevent abandonment or recover the value of the work from the abandoning assignee. Prior to serving notice, her position is less certain. 
Copyright Office to define a standard and administer a process for recording copyright abandonments. ${ }^{264}$

At the administrative level, a number of reforms could reduce the information costs complicating copyright abandonment. Empowered by Congress, the Copyright Office could develop a robust administrative mechanism for evaluating, recording, and publicizing copyright abandonment. ${ }^{265}$ Today, notices of abandonment are filed using the standard recordation form, just like any other transfer. And the Office disclaims any statement as to the legal effect of such a filing. Instead, the Copyright Office could promulgate a form specifically for abandonment, one that complies with a legal standard articulated clarified by the courts or endorsed by Congress. While the Office's determinations of abandonment-like its registration

${ }^{264}$ Some jurisdictions provide clear statutory copyright abandonment procedures. For example, Section 21 of Indian Copyright Act provides:

(1) The author of a work may relinquish all or any of the rights comprised in the copyright in the work by giving notice in the prescribed form to the Registrar of Copyrights or by way of public notice and thereupon such rights shall, subject to the provisions of sub-section (3), cease to exist from the date of the notice.

(2) On receipt of a notice under sub-section (1), the Registrar of Copyrights shall cause it to be published in the Official Gazette and in such other manner as he may deem fit.

(2A) The Registrar of Copyrights shall, within fourteen days from the publication of the notice in the Official Gazette, post the notice on the official website of the Copyright Office so as to remain in the public domain for a period of not less than three years.

(3) The relinquishment of all or any of the rights comprised in the copyright in a work shall not affect any rights subsisting in favour of any person on the date of the notice referred to in sub-section (1).

For a detailed survey of international copyright abandonment regimes, see Guadamuz, supra note 3.

265 The scope of the Copyright Office's existing authority over such rules is uncertain. The most relevant, explicit statutory authority the Office could claim provides that "Any transfer of copyright ownership or other document pertaining to a copyright may be recorded in the Copyright Office if the document filed for recordation bears the actual signature of the person who executed it, or if it is accompanied by a sworn or official certification that it is a true copy of the original, signed document." 17 U.S.C. $§ 205$ (a) (2018). Even if this language is sufficient to support an effort by the Office to develop more robust procedures for abandonment, given the importance of the question, we think Congress owes the Office some measure of additional guidance. 
decisions - would not be dispositive, they fall squarely within the Office's expertise and would be entitled to judicial deference. ${ }^{266}$

Crucially, the Office should not charge a fee for filing a notice of abandonment. Currently, the standard fee of $\$ 105$ for recordation applies. This creates a paradoxical scenario in which obtaining a copyright is free, while ridding yourself of one is costly. Ideally, the abandonment forms would be made available through a simple online interface, allowing owners to dedicate their works easily and quickly, with appropriate safeguards to prevent fraudulent notices. ${ }^{267}$

These filings could in turn populate a searchable registry of abandoned works. Users could locate public domain works by title, type of work, author, owner, date of vesting, and date of abandonment. The Office could even make copies of abandoned works available for download. ${ }^{268}$ Today, the Office provides no simple way to identify works that have been abandoned, defeating the purpose of abandonment from the perspective of potential users.

These proposals operate against a backdrop of considerable private efforts to reduce the transaction costs of abandonment. Millions of works have been distributed under the terms of $\mathrm{CC} 0$ and similar instruments. As a third step, the law-whether through Congress, courts, or the Copyright Office-should clarify the public domain status of works subject to such private dedication instruments. ${ }^{269}$ Although a clear, legally-recognized administrative mechanism for abandonment would prove valuable, we do not intend that process to function as an exclusive means of abandonment. The choice to rely on a private instrument like $\mathrm{CC} 0$ or an individually-

\footnotetext{
${ }^{266}$ See generally Aaron Perzanowski, The Limits of Copyright Office Expertise, 33 BERKELEY TECH. L.J. 733 (2018).

${ }^{267}$ Unlike other property records, which could be manipulated to falsely indicate ownership of an asset, the abandoned works registry does not purport to create exclusive rights. As a result, the incentives to falsify abandonment records would be low. Nonetheless, we recommend requiring any such abandonment be accompanied by a statement, under penalty of perjury, that the filer has a good faith belief that they own the work in question.

${ }^{268}$ User-friendly design has not been a hallmark of the Copyright Office's internet presence historically. But the Office has dedicated significant resources to its digital transition in recent years. And given the Office's status as a division of the Library of Congress, which regularly provides public domain collections to the public, such a system should be achievable.

${ }^{269}$ The Library of Congress, which houses the Copyright Office, relies on CC0 when it chooses to make its own works available for public use. See Legal, LIBRARY OF CONGRESS, https://www.loc.gov/legal/\#copyright.
} 
crafted statement of abandonment, rather than a federal form, should not preclude abandonment. However, we would expect over time that either the existing $\mathrm{CC} 0$ instrument would be recognized as a valid abandonment, or that it would evolve, if necessary, to satisfy whatever federal standard emerged. If so, owners could include the $\mathrm{CCO}$ designation on abandoned works to signal their public domain status, providing a quick way for users to determine whether a work's copyright status. ${ }^{270}$

Private organizations like Creative Commons or the Internet Archive might be better positioned to host and operate a database of abandoned works, particularly since those entities could more easily include works abandoned through private mechanisms in addition to those filed with the Copyright Office. ${ }^{271}$ Ideally, at least one complete and authoritative registry would allow the public to search for abandoned works.

These reforms would provide a clear signal to owners about how to abandon their copyrights, one backed by the authority of law. And by providing that information online and in easily accessible form, they would help users access public domain resources. Related, these moves would channel abandonment to a handful of approved mechanisms by either prompting an official and effective Copyright Office form or endorsing existing instruments like $\mathrm{CC} 0$. So while the current legal landscape consists of a confusing multiplicity of ways to potentially relinquish one's rights in a work of authorship, these reforms would reduce owners' decision costs and promote abandonment generally.

\section{B. Recalibrating Incentives}

Formalizing and streamlining pathways to memorialize and publicize abandonment promises to reduce confusion and transaction costs. This clarifies the route to abandonment for owners who are inclined to relinquish their copyrights. It does not, however, do anything to allay the error costs that might deter an owner from

\footnotetext{
${ }^{270}$ Other scholars have argued that the Copyright Office should create a public domain indication along the lines of the familiar "C)" symbol. See Asay, supra note 104 at 802 (arguing for a "PD" mark to indicate public domain status). In order to make information costs as low as possible, we think the best strategy would be to adopt current usage signaling public domain status, hence our suggestion that the Copyright Office embrace "CCO" as a signaling device.

${ }^{271}$ CCO is machine readable, like the Creative Commons suite of licenses, facilitating searchability. $\mathrm{CC} 0$, https://wiki.creativecommons.org/wiki/CC0.
} 
relinquishing rights to their work when it is essentially costless to them yet beneficial to the public. We thus consider two types of strategies designed to bend the incentives of these owners toward abandonment: carrots (positive incentives) and sticks (negative penalties).

\section{Carrots}

Tax incentives. One approach to altering the cost calculus in favor of abandonment would be to leverage the tax system to provide rights holders marginal economic incentives to part with their works. Existing tax law countenances donations of intellectual property, including copyrighted works, to charitable organizations and branches of state and federal government. ${ }^{272}$ For example, Irving Berlin donated his interest in "God Bless America" to a trust that supports the Boy Scouts and Girl Scouts. ${ }^{273}$ As noted above, Carol Highsmith has donated more than 50,000 images to the Library of Congress on a copyright-free basis. ${ }^{274}$ The Library has also elected to make other works in its collections available for unrestricted public use. ${ }^{275}$ But nothing requires that works donated to the Library of Congress, or any other government entity, be dedicated to the public domain. ${ }^{276}$

Likewise, the donation of works to a non-profit organization need not result in abandonment. Those contributions are merely assignments - transfers of copyright ownership from one party to another. In both cases, abandonment would require some further evidence of an intent to eliminate the copyright, either by the donor at the time of transfer or by the donee organization after the fact. Whether donated to the Library of Congress, an existing organization like Creative Commons or the Internet Archive, or to a newly formed non-

27226 U.S.C. $\$ 170$ (c) (2018). (defining "charitable contribution" to include a gift to "A State, a possession of the United States, or any political subdivision of any of the foregoing, or the United States or the District of Columbia, but only if the contribution or gift is made for exclusively public purposes."

${ }^{273}$ William Glaberson, Irving Berlin Gave the Scouts A Gift of Song, N.Y. TimeS, Oct. 14, 2001, https://www.nytimes.com/2001/10/14/us/irving-berlin-gave-thescouts-a-gift-of-song.html.

${ }^{274}$ See supra note 56. Highsmith's initial gift to the Library included a number of transparencies, negatives, and prints, but in the same document she "dedicate[d] to the public all rights, including copyrights, throughout the world ... in this collection." Id. at Exhibit I.

${ }^{275}$ See supra note 113.

${ }^{276}$ The government can own copyrights assigned by non-governmental authors. 17 U.S.C. § 105 (2018). 
profit that committed to dedicating works to the public domain, such works could qualify as charitable contributions. ${ }^{277}$

But the current tax treatment of copyrighted works provides little incentive for owners to part with them. The Internal Revenue Code distinguishes between two types of copyrighted works for the purposes of charitable deductions: those donated by their creators and those donated by non-creators. Since 1969, if the creator of a work donates it, they are not entitled to deduct its fair market value, but only. out of pocket expenses associated with the work that have not been previously deducted. ${ }^{278}$ In many cases, that translates to no deduction whatsoever. ${ }^{279}$ In contrast, works donated by someone other than their creators were deductible historically at fair market value. ${ }^{280}$ But in 2004, Congress tightened the rules for donations of intellectual property amid concerns about patent valuation abuses. ${ }^{281}$ Under the new rules, the donor's tax deduction is the lesser of asset's fair market value or its tax basis. Typically, that tax basis is very small, and again, in many cases it is zero. ${ }^{282}$

More generous deducibility could yield an increase in abandonment. But it may sacrifice significant federal revenue in the process. The IRS discourages large-scale fraud by requiring a qualified appraisal for any charitable deductions over $\$ 5000 .{ }^{283}$ But

${ }^{277}$ Martin Skladany has offered a similar proposal to encourage the dissemination newly-designated public domain works. MARTIN SKLADANY, Big COPYRIGHT VERSUS THE PEOPLE (2018).

${ }^{278}$ Charitable contributions of creators are governed by the general rule in 26 U.S.C. $\S 170(\mathrm{e})(1)(\mathrm{A})$. Income from their sale is not considered a capital asset, so the value is reduced by any gain from a hypothetical sale. $I d$. $\S 1221(\mathrm{a})(3)$.

${ }^{279}$ Xuan-Thao Nguyen \& Jeffrey A. Maine, Giving Intellectual Property, 39 U.C. DAVIS L. REV. 1721 (2006).

${ }^{280} \mathrm{Id}$.

${ }^{281}$ See Jobs and Growth Tax Relief Reconciliation Act of 2003, S. 6457, 108th Cong. (2003) (noting "widespread abuse involving donations of patents and similar property").

${ }^{282}$ Nguyen \& Maine, supra note 279. Deductions arising from such donations must be reduced by any long-term capital gains. 26 U.S.C. $\S 170(\mathrm{e})(1)(\mathrm{B})(\mathrm{iii})$. To partially address the disincentive created by these harsher rules, Congress provided for future deductions, over a 12-year phase-out period, based on any revenue derived by the donee from the gift. $I d . \S 170(\mathrm{~m})(3)$. This provision does little to encourage copyright abandonment.

283 Internal Revenue Service, Publication 561, Determining the Value of DONATED PROPERTY 8-9 (2017). In addition, for items valued at $\$ 50,000$ or more, the IRS Art Advisory Panel provides an additional layer of scrutiny. INTERNAL REVENUE MANUAL 4.48.2. 
$\$ 1000$ or $\$ 100$ deductions for abandoned photos, emails, and mediocre poetry could add up. Conversely, there's a risk that given the recent increase in the standard deduction, itemizing low dollar value donations of works might insufficiently incentivize individual copyright holders. Finally, attaching a monetary benefit to an otherwise altruistic act like donating a work to the public may actually dissuade would-be abandoners by framing the act in terms of financial self-interest rather than concern for others. ${ }^{284}$

Cash incentives. A simpler approach would offer copyright holders modest cash payments to abandon. If, rather than charging rights holders $\$ 105$ to file a notice of abandonment, the Copyright Office gave abandoning rights holders $\$ 10$ per work, we would expect to see a considerable increase in abandonment.

But this approach faces its own set of challenges. First, calibrating payments to induce the optimal levels of abandonment would be no easy task. A payment of $\$ 1000$ per work would undoubtedly enrich the public domain, but may lead many songwriters or photographers to abandon works with considerable commercial potential. Second, cash payments increase the risk of gaming the system. Even at $\$ 10$ each, a dedicated, if unskilled, poet could make a tidy sum producing soon-to-be-abandoned works. An annual or lifetime cap on payments could mitigate some of that risk. But more generally, a cash-based abandonment incentive could prove massively expensive given the number of unwanted copyrighted works produced each year. Justifying that expense in light of other demands on the federal budget would be difficult.

Of course, there is nothing preventing a private entity from investing its resources in enriching the public domain. The Arcadia Fund, for example, has made an $\$ 850,000$ grant to MIT Press to support open access monographs. ${ }^{285}$ Perhaps public domain dedication would prove an even more attractive investment. Even forprofit corporations may have some incentive to foot the bill for abandonment, although they are more likely to prefer exclusive licenses to abandonment.

\footnotetext{
${ }^{284}$ See Dave Fagundes, Why Less Property Is More, 103 IowA L. REV. 1361, 139598 (2018) (citing literature showing that self-interest and altruism tend to compete directly with each other, and that the former tends to predominate).

${ }^{285}$ MIT Press, The MIT Press Receives a Generous Grant from the Arcadia Fund to Develop and Pilot a Sustainable Framework for Open Access Monographs, Oct. 3, 2019, https://mitpress.mit.edu/blog/mit-press-receives-generous-grant-arcadiafund-develop-and-pilot-sustainable-framework-open.
} 
Golden swan insurance. In Part II, we discussed "golden swans"- works that generate substantial and unexpected value late in the copyright term - and authors' fears of parting with such works in light of the costlessness of owning a copyright. The golden swan problem is a matter of risk assessment clouded by optimism bias. But insurance may furnish a solution.

Consider a system that promised any owner who abandoned their work compensation if that work earned significant revenue either through being republished or incorporated into a derivative work. Such a system should be funded and managed by a federal agency, like the Copyright Office, since private funding would prove infeasible. Given that the public receives the benefit of abandonment, public funding makes some measure of sense even if securing significant federal dollars for golden swan insurance is unlikely. Aside from that budgetary hurdle, the chief practical challenges of such a system would be accounting for the profit earned by a given work and administering payouts. One partial solution would be to keep the compensation structure as simple as possible. The policy could give donors of abandoned works a set rate (e.g., \$10,000) if their abandoned work earns gross revenue ${ }^{286}$ in excess of some threshold (e.g., \$100,000). ${ }^{287}$ This may undercompensate owners whose works become true blockbusters. But such outcomes are vanishingly rare. The aim of the policy is less to ensure full compensation and more to assuage owners' hesitance to abandon a potential golden swan. The mere possibility of compensation may suffice to overcome owners' optimism bias. ${ }^{288}$

${ }^{286}$ Abandoned works are in the public domain, but they may still be used to create
revenue, such as by creating valuable derivative works.
287 Admittedly, determining the contribution of a particular work to revenues
generated by a derivative work presents a more complex challenge.
288 A rough analogy is FEMA flood insurance. The federal government offers
residents of homes in designated high-risk areas low-cost insurance to compensate
them for damage in the event of a flood. The policies do not promise full
compensation, but only reimbursement up to a cap well below the property's value.
They thus function as an enticement to offset concerns about possible low-
probability, high-impact risks. But unlike FEMA flood insurance, golden swan
policies would have vanishingly small payout risks. And the behavior they
incentivize is socially beneficial (dedicating works to the public domain) as opposed
to socially harmful (building homes likely to contribute to increased environmental
damage). See Bonnie Kristian, The perverse incentives of the National Flood
Insurance Program, THE WEE, Aug. 29, 2017, 


\section{Sticks}

If retaining low-value copyrights is socially harmful, the copyright system could impose costs on rights holders to encourage abandonment. Most forms of intellectual property require some payment or action in order to maintain rights. The failure to pay maintenance fees, ranging as high as $\$ 7400$, results in the loss of patent rights. ${ }^{289}$ Trademark owners must use their marks in commerce and renew their registrations. ${ }^{290}$ And trade secret owners must make reasonable — and often costly — efforts to maintain their secrets.

But copyright has parted from its cognate fields. Copyright holders bear no costs to maintain ownership. In large part, this reflects compliance with international obligations. The Berne Convention requires that "the enjoyment and exercise" of copyrights "shall not be subject to any formality." 291 Requiring that authors take any affirmative action to renew their copyrights represents an archetypal violation of Berne. ${ }^{292}$

Scholars have offered a number of proposals to address the downsides of formality-free copyright. ${ }^{293}$ Larry Lessig proposed the Public Domain Enhancement Act, which would have required owners to pay a $\$ 1$ fee fifty years after a work's first publication, and again every ten years until expiration. ${ }^{294}$ In a different vein, Richard Posner and Bill Landes have advocated for indefinite copyrights, subject to

https://theweek.com/articles/721185/perverse-incentives-national-flood-insuranceprogram.

$289 \quad 15 \quad$ U.S.C. $\quad \S \quad 1127$; USPTO, Maintain Your Patent, https://www.uspto.gov/patents-maintaining-patent/maintain-your-patent.

29015 U.S.C. $§ 1059$, USPTO, Overview of Trademark Fees, https:/www.uspto.gov/trademark/fees-payment-information/overview-trademarkfees.

${ }^{291}$ Berne Convention for the Protection of Artistic and Literary Works art. 5 (1971). 292

293 See, e.g., Chris Sprigman, supra note 91 at 545-67 (outlining policy options to counter challenges arising in the wake of eradication of copyright formalities).

${ }^{294}$ H.R. 2408 (109th Congress, 2005). The PDEA was twice proposed in the U.S. House of Representatives; it died in committee both times. The proposal attempted to avoid the Berne problem by limiting its application to works first published in the United States. This would reduce the effective scope of the legislation but would save it from violating Berne, which adopts a national treatment principle: Nations may disadvantage their own copyrights, though they cannot do so to foreign ones. 
an ongoing obligation to renew. ${ }^{295}$ Although these proposals reinstate formal requirements that could shift the calculus in favor of abandonment, they would also increase the rate of forfeiture through unintentional failures to comply.

To remain compliant with the Berne Convention and focus exclusively on abandonment, consider this alternative: Owners of registered works would owe a tax of $\$ 100$ per year on each work starting in the fifteenth year of the copyright term. This tax would not be paired with automatic forfeiture of copyright. It would be penalized instead by the standard IRS rules for nonpayment of taxes. In this case, Berne presents no obstacle because enjoyment and exercise of the copyright is not contingent on payment of a fee or compliance with a formality.

This approach obviously represents a much lighter-touch intervention than the other sticks discussed above. Some owners of registered works - especially high-value works that are earning substantial revenue-will find $\$ 100 /$ year a fully justified cost in relation to their royalty income. Wealthy owners may regard the amount as trivial regardless of the value of their work. But for authors of works that are no longer producing income, it will force them to consider abandonment. In this sense, it operates as a "nudge" in the now-familiar phrasing of Sunstein and Thaler. This tax proposal does not coerce, and it will not affect the conduct of most owners. But at the margins, it will encourage owners to weigh abandonment as an option.

C. Availability and Abandonment as a Social Practice

Optimizing abandonment also requires thinking about it not only as a doctrine but also as a social practice. One explanation for the rarity of abandonment is its absence from the copyright lexicon. ${ }^{296}$

${ }^{295}$ William M. Landes \& Richard A. Posner, Indefinitely Renewable Copyright, 70 U. CHI. L. REV. 471 (2003). The Landes and Posner proposal flies in the face of the Constitution's mandate that Congress may create copyrights only for "limited times." U.S. Const. art I, § 8, cl. 8. Posner and Landes foresaw this objection, and argued that the constitutional meaning of "limited times" is unclear and that any renewal short of infinity is limited. Landes \& Posner, supra note 295 Id. at 472-73. 296 Two types of works - software and photography — are abandoned with higher frequency than others. We believe this behavior suggests a desire for abandonment that could be better facilitated by law reform. It also suggests the potential for 
Copyrights owners know that they may transfer, license, and sublicense their works, or hang onto them for life and devise them as part of their estate. The Copyright Act contains a detailed statutory scheme governing all these options, but it nowhere so much as uses the term "abandonment." 297 Scholarly texts that otherwise exhaustively canvass the entirety of copyright pay scant attention to abandonment, often referring briefly to the doctrine only as a defense to infringement, not as an affirmative strategy owners may wish to undertake. ${ }^{298}$ A major part of the challenge, then, is centering abandonment as a practice that owners may choose to pursue.

In short, abandonment has an availability problem. Among the major cognitive biases that behavioralists have shown to distort our thinking is availability. When a phenomenon is especially salient, we are inclined to overestimate its likelihood. ${ }^{299}$ For example, people tend to avoid the beach after highly publicized shark attacks, even though the likelihood of shark attacks is no greater due to a single wellpublicized incident. ${ }^{300}$ By the same token, where a given phenomenon is not immediately familiar, people may wrongly assume that it is generally unavailable. For example, if you live in a tech-savvy city like San Francisco, you are unlikely to know anyone who lacks an internet connection, and are thus much more likely to overstate the national prevalence of internet connectivity. ${ }^{301}$ For similar reasons, copyright holders may fail to abandon their copyrights, even when doing so suits their needs, simply because abandonment's obscurity renders it unavailable as a social practice.

emergent trends in favor of abandonment in other creative communities, among authors and filmmakers for example, where the practice is far less prevalent.

${ }^{297} 17$ U.S.C. $\S \S 201-205$ (defining ownership, outlining scheme for transfer and termination of transfer, and establishing means to record copyright-related transactions).

${ }^{298}$ E.g., Joyce et al. (10th ed. 2018).

${ }^{299}$ Amos Tversky \& Daniel Kahneman, Judgment Under Uncertainty: Heuristics and Biases, in Judgment Under UnCertainty: Heuristics AND Biases 3, 11 (Daniel Kahneman, Paul Slovic, \& Amos Tversky, eds., 1982) (outlining the nature of the availability heuristic).

300 This is an example of what Timur Kuran and Cass Sunstein have termed an "availability error": Behavior that is suboptimal because of an excess of availability. See Timur Kuran \& Cass Sunstein, Availability Cascades and Risk Regulation, 51 STAN. L. REV. 683, 703-15 (1999).

301 See Jamie Madigan, The Availability Heuristic Is Always On, Psychology TODAY, Apr. 15, 2013 (discussing this example). 
Neither courts, nor Congress, nor the Copyright Office have the power to immediately render abandonment salient in the minds of owners. That said, the strategies we suggest in this Part may help to ameliorate abandonment's availability problem. Simply providing a visible pathway to abandoning works will serve to highlight the practice as one that owners may choose, alongside transfer and licensing. ${ }^{302}$ This pathway may serve as a focal point around which the social practice of abandonment may coalesce. As a number of studies have shown, behaviors are much more likely to emerge when there is some pattern or framework to guide and encourage their development. ${ }^{303}$ Independently, incentivizing abandonment, either via carrot or stick, could send a message about the desirability of abandonment. The work of private organizations like Creative Commons has been, and will continue to be, crucially important in increasing the availability and ease of abandonment, and in creating a culture in which it is celebrated. Together, these twin forces could help to bring abandonment out of the shadows and make it an available, and likely more generally used, social practice for copyright owners.

\section{CONCLUSION}

One might look at the near-absence of scholarly attention to copyright abandonment as an indication that the doctrine is of little consequence. This Article has dispelled that misapprehension. By situating copyright abandonment within the broader resurgence of interest in abandonment generally, we have offered a competing theory of abandonment as a relinquishment of rights that reconciles apparent contradictions within the unilateral transfer approach. We have also highlighted the significant stakes of the doctrine, for individual authors and the public writ large, by exploring both the economic calculus and the counterintuitive reality of copyright abandonment. But as our detailed canvassing of the positive law of copyright abandonment reveals, the doctrine is fractured and the

${ }^{302}$ Cf. Richard H. Thaler, Cass R. Sunstein \& John P. Balz, Choice Architecture, 1415 (2010) (showing that visible phenomena are more available and thus more likely to affect decisions), available at https://papers.ssrn.com/abstract=1583509.

303 The seminal work on how behavior coalesces around focal points is Thomas Schelling, The Strategy of Conflict (1960). Schelling showed that conduct naturally coalesces around locations and behaviors that are socially salient, famously illustrated by his experiment in which New Yorkers successfully met each other even without a given date or time because they all familiarly assumed to do so at noon at Grand Central Station. 
mechanism for effective abandonment remains uncertain. Optimizing abandonment demands, at the very least, clear and reliable legal and administrative pathways. Beyond that, encouraging prosocial abandonment of copyright may require shifting rights holder incentives and, more promisingly, the development of social practices that value the public domain and copyright's constitutional aspirations. 